Review

\title{
From Molecular to Nanotechnology Strategies for Delivery of Neurotrophins: Emphasis on Brain-Derived Neurotrophic Factor (BDNF)
}

\section{Claire Géral ${ }^{1,2}$, Angelina Angelova ${ }^{1,2, *}$ and Sylviane Lesieur ${ }^{1,2}$}

1 CNRS UMR8612 Institut Galien Paris-Sud, 5 rue J.-B. Clément, F-92296 Châtenay-Malabry, France; E-Mails: clairegeral@live.fr (C.G.); sylviane.lesieur@u-psud.fr (S.L.)

2 Univ Paris Sud 11, 5 rue J.-B. Clément, F-92296 Châtenay-Malabry, France

* Author to whom correspondence should be addressed; E-Mail: Angelina.Angelova@u-psud.fr; Tel./Fax: +33-1-46-83-53-12.

Received: 13 November 2012; in revised form: 30 January 2013 / Accepted: 5 February 2013 / Published: 8 February 2013

\begin{abstract}
Neurodegenerative diseases represent a major public health problem, but beneficial clinical treatment with neurotrophic factors has not been established yet. The therapeutic use of neurotrophins has been restrained by their instability and rapid degradation in biological medium. A variety of strategies has been proposed for the administration of these leading therapeutic candidates, which are essential for the development, survival and function of human neurons. In this review, we describe the existing approaches for delivery of brain-derived neurotrophic factor (BDNF), which is the most abundant neurotrophin in the mammalian central nervous system (CNS). Biomimetic peptides of BDNF have emerged as a promising therapy against neurodegenerative disorders. Polymer-based carriers have provided sustained neurotrophin delivery, whereas lipid-based particles have contributed also to potentiation of the BDNF action. Nanotechnology offers new possibilities for the design of vehicles for neuroprotection and neuroregeneration. Recent developments in nanoscale carriers for encapsulation and transport of BDNF are highlighted.
\end{abstract}

Keywords: neurotrophin BDNF delivery; therapeutic protein encapsulation; lipid nanocarriers; cubosomes; neurotrophic gene vectors; peptide mimetics; TrkB receptor; neurodegenerative disease therapy 


\section{Introduction}

\subsection{Burden of Neurodegenerative and Psychiatric Diseases Resulting from Neurotrophin Impairment}

Neurotrophic factors are proteins, which play an important role in proliferation, differentiation, maintenance, plasticity, survival and function of neurons in the central and peripheral nervous systems [1-9]. These neuroprotective molecules exert considerable control over the life and death pathways in cells [10-31]. They participate in local responses to various types of neuronal stressors [32-53]. In mammals, the neurotrophin brain-derived neurotrophic factor (BDNF) is a principal regulator of axonal growth and connectivity, neuronal differentiation, survival and synaptic plasticity [6,29,54-87]. It is a key molecular target in the development of drugs against neurological disorders [3-6,19,23,31,32,88-108]. Several studies have shown the involvement of BDNF in the pathogenesis of neurodegenerative diseases and psychiatric disorders, like depression and schizophrenia $[4,6,15,16,27,37,50]$. The neurotrophic actions of BDNF have been established with diverse neuronal populations [109-148]. In the periphery system, BDNF has shown neurotrophic actions on small fiber sensory neurons involved in sensory neuropathies. In the central nervous system (CNS), BDNF has been found to be a potent neurotrophic factor for cholinergic neurons, which are depleted in Alzheimer's disease; for dopaminergic neurons of the substantia nigra, which are lost in Parkinson's disease; as well as for cerebral and spinal motor neurons, which degenerate in amyotrophic lateral sclerosis (ALS) [12-47].

Despite these promising results, the therapeutic delivery of recombinant human BDNF has raised a number of problems related to its pharmacokinetic profile, short in vivo half-life, uncertain passage through the blood-brain barrier (BBB) and high manufacturing costs [1]. A major question has been how to assess the amount of BDNF that reaches the affected neurons, as this compound is relatively unstable and only a small fraction of it can cross the BBB after administration. If the amount of administered BDNF is too small, it may not be sufficient to produce the required neurotrophic effects. On the contrary, if the BDNF quantity is too large, it may be toxic and dangerous, because of side effects. Besides regulating the survival, maintenance and differentiation of neurons [6], BDNF also modulates the activity-dependent neuronal plasticity, which is essential for the functional and structural refinement of the neuronal circuits, as well as for learning and memory [11,25,73]. Uncontrolled BDNF administration may interfere with these mechanisms and give rise to serious side effects, such as epilepsy. It has been reported that high BDNF levels may downregulate the expression of the TrkB receptor [85-87], thus hampering the signaling pathways activated by BDNF and blocking any beneficial neuroprotective effects $[20,49,56,63]$. Therefore, it has been concluded that BDNF delivery should be localized [5] and targeted in specific brain regions, which are essential for the treatment of particular neurodegenerative diseases (Alzheimer's disease, Parkinson's disease, Huntington's disease, ALS, multiple sclerosis, stroke, Rett syndrome, etc.).

The rational design of neurotrophin-based therapeutics and delivery systems [53,63,149-229] requires a good understanding of the structures of the neurotrophic proteins and their receptors, as well as of their interactions and mechanisms of action at the molecular level. The involved biochemical structures and signal transduction pathways are briefly reviewed here, as the clinical efficiency of any 
neurotrophin-based drug delivery system should be evaluated by its capacity to modulate the BDNF levels and activate receptor TrkB signaling [35-87].

\subsection{Mechanism of Neurotrophin Action}

\subsubsection{Structure-Activity Relationships for Neuroprotection}

Neurotrophic actions are exerted by four members of the neurotrophin family: brain-derived neurotrophic factor (BDNF), nerve growth factor (NGF), neurotrophin-3 (NT-3) and neurotrophin-4/5 (NT-4/5) [3,11]. Neurotrophins form homodimers of about $27 \mathrm{kDa}$ and have a common structural motif, including three disulfide bridges $[39,40]$. Each monomeric sequence consists of approximately 120 amino acids and forms three pairs of anti-parallel $\beta$-sheets connected to four loops. The neurotrophic proteins exert their biological activity in a dimeric state (Figure 1). The amino acid residues in their $\beta$-sheets are highly conserved and are essential for the maintenance of the tertiary structure of the neurotrophins. At variance, the $N$ - and $C$-terminal regions and the loops $1-4$ of the proteins are variable and play a functional role in the receptor activation upon ligand binding [74,77].

Figure 1. Schematic presentation of a neurotrophin (brain-derived neurotrophic factor (BDNF)) dimer with designation of the four loops participating in receptor recognition and binding.

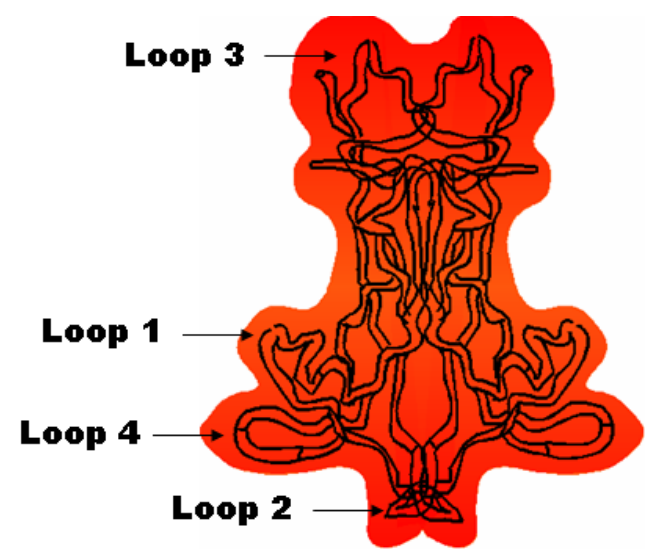

The neurotrophic proteins operate by binding to two types of receptors: a common receptor, $\mathrm{p} 75^{\mathrm{NTR}}$, which is a member of the family of the tumor necrosis factor receptors, and a second receptor of a high affinity, the tropomyosin-related kinase (Trk) receptor, belonging to the large family of tyrosine kinase receptors [74,77]. All neurotrophic factors have the same affinity for the $\mathrm{p} 75^{\mathrm{NTR}}$ receptor $\left(\mathrm{K}_{\mathrm{d}} \approx 10^{-9} \mathrm{M}\right)$, but their binding to the Trk receptors is more selective and with greater affinity $\left(\mathrm{K}_{\mathrm{d}} \approx 10^{-11} \mathrm{M}\right)$. NGF activates the TrkA receptor; BDNF and NT-4/5 activate the TrkB receptor; and NT-3 activates the TrkC receptor. The Trk receptors have high sequence homology between them. Their extra-cellular domains have been classified into five subdomains on the basis of the sequence similarity with other known receptors: a leucine-rich region (domain 2), located between two cysteine-rich regions (domains 1 and 3) and adjacent to the two immunoglobulin-like domains (domains 4 and 5) in the proximity of the cell membrane (Figure 2). The intracellular tyrosine kinase domain is connected to the extracellular region via a toroidal membrane element. Despite the similar 
Trk protein structures and sequences, the receptor interactions with each neurotrophin are distinct and appear to involve a large number of discrete contacts. Variable regions, as well as slight differences between the binding sites, distinguish the neurotrophins and are important for the specificity and the binding affinity for their receptors [74].

Figure 2. Schematic presentation of the BDNF-activated tropomyosin-related kinase B (TrkB) signal transduction. The neurotrophin binding to the TrkB receptor controls three major intracellular signaling pathways [77]. Receptor phosphorylation and activation of Ras results in activation of the mitogen-activated protein kinase (MAPK)-signaling cascade, which promotes neuronal differentiation, including neurite outgrowth and neurogenesis. Activation of phosphoinositol-3 kinase (PI3K)/protein kinase B (AKT) pathway, through Gab1, promotes survival and proliferation of neurons and other cells. Activation of phospholipase C- $\gamma$ (PLC- $\gamma$ ) results in activation of $\mathrm{Ca}^{2+}$ and protein kinase $\mathrm{C}$-regulated pathways that promote synaptic plasticity and neurotransmission. Each of these signaling pathways also regulates gene transcription (CREB, cAMP response-element binding protein).

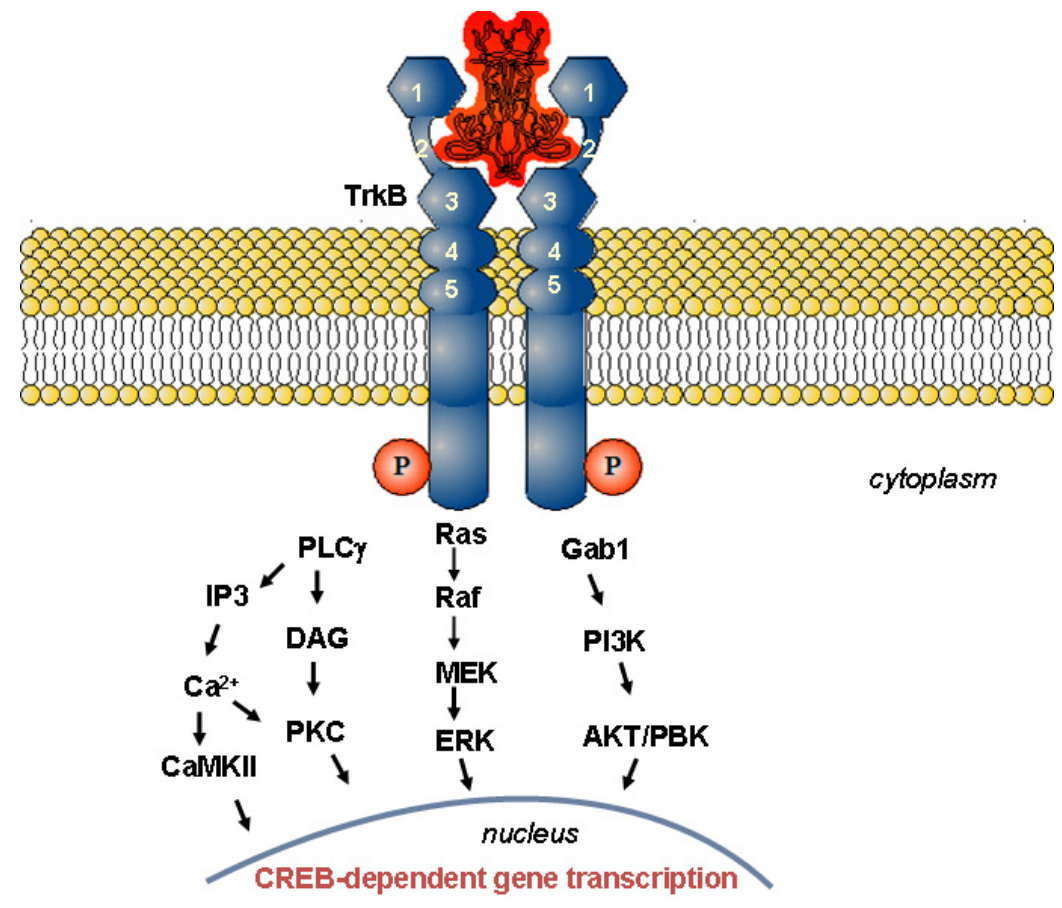

The available crystallographic neurotrophin structures, BDNF/NT-3 (PDB code 1B8M) and BDNF/NT-4/5 (PDB code 1BND) [39,40], as well as the structural data for a neurotrophin co-crystallized with fragments of its receptor (PDB code 1HCF), have allowed for a better understanding of the neurotrophin-receptor interactions [77]. In particular, it has been established that the interaction of the TrkB receptor with BDNF is mediated by multiple contacts. The occurring cooperative binding activates the receptor through receptor dimerization [69]. Indeed, the amino acid structural elements, like Lysine 96 and Arginine 97 in loop 4 of BDNF and Glutamine 84 in its $\beta$ sheet, as well as the residues 45-49 in loop 2 and 26-35 in loop 1, appear to be essentially important for BDNF activity, as they mediate the BDNF/TrkB contacts [69]. The TrkB receptor activation 
induces autophosphorylation of the intracellular tyrosine kinase domain, thereby triggering a signaling cascade to allow neurite outgrowth and neuronal survival or differentiation [77,78]. In vitro studies with various cell types have revealed that a complex signaling pathway is set up in the cells upon activation and dimerization of the TrkB receptor after BDNF binding [6,54,64,68,70]. Figure 2 schematically presents the signal transduction pathways, which control the neuronal cell adhesion, migration, survival, synaptic plasticity and neurogenesis upon activation or inhibition of the corresponding proteins and genes.

\subsubsection{Physiological Role of BDNF in Relation to Neurodegenerative Disorders}

A number of studies have presented evidence that the alteration of the BDNF levels in the CNS can cause multiple pathologies [1-6]. BDNF levels are generally decreased in the brain of patients suffering from Alzheimer's, Parkinson's or Huntington's diseases [63]. Owing to the fact that this neurotrophic protein is continuously required for the maintenance and survival of mature neuronal phenotypes, it has been suggested that changes in its concentration or its distribution may lead to neurodegenerative pathologies [1]. For instance, a significant drop in the BDNF levels in the striatum has resulted in clinical manifestations of Huntington's disease [2,17]. Studies performed on stroke, in either mice or humans, have indicated that the release of BDNF has been altered [25]. Whereas BDNF hyperactivity has been detected in epilepsy, autism and manic-depressive psychosis [49], a decreased activity of BDNF has been established in the hippocampus of patients with severe depression [6,50]. Impaired signaling, induced by BDNF, has been reported for schizophrenia [15,36]. BDNF has exerted effects also on food intake, obesity and associated metabolic conditions in animal models $[13,51,55,65]$. It plays a role in the mechanisms of alcohol and drug addiction [25].

For neurodegenerative disorders, BDNF has been validated as a therapeutic target, since the endogenous administration of the neurotrophin has produced beneficial effects [1,4,7-9]. BDNF promotes neuronal cell survival, adhesion, migration, neurogenesis, long-term potentiation and plasticity [25-31,43,81]. This neurotrophin appears to control the mechanisms of neuroprotection and memory [11,12]. Indeed, increasing of the BDNF levels has contributed to modifying the neurological disease progressions by diminishing neuronal death $[1,5,63]$. It has been shown that the antidepressant effects of BDNF are mediated by the MAPK/ERK and PI3K/Akt intracellular signaling pathways [59,111]. Neuroprotection has been established also through the Bcl-2/Bax-dependent mechanism, i.e., by upregulation of the anti-apoptotic protein $\mathrm{Bcl}-2$ and downregulation of the pro-apoptotic Bax protein upon BDNF administration [155].

\section{Therapeutic Strategies Designed for Delivery of Neurotrophins}

Neurotrophins are challenging candidates for drug development, because of their low bioavailability for therapeutic targets and insubstantial pharmacokinetic behavior. Generally, the use of peptides and proteins in medicine has been hampered by the short in vivo half-life, poor bioavailability, resulting from proteolysis or hydrolysis, and marginal permeability through biological barriers. The successful delivery of therapeutic protein molecules has required the development of carrier systems that avoid (i) rapid protein elimination from the cerebral circulation owing to enzymatic degradation, (ii) capture 
by the reticuloendothelial system, (iii) macromolecular accumulation in non-targeted tissues, as well as (iv) undesired immune responses.

A starting point towards improvement of the neurotrophin drug bioavailability to brain is provided by a summary of the different therapeutic strategies for administration of such neuroprotective molecules [53,56,88-230]. This helps define future roads for controlled protein delivery of higher efficiency. Table I summarizes the major approaches for neurotrophin delivery applied to human subjects and animal or in vitro models. To our knowledge, none of these approaches has resulted in a marketed formulation of pure BDNF. The commercial product, cerebrolysin ${ }^{\circledR}$ (Ebewe Neuro Pharma, Unterach, Austria), appears to be a mixture involving fragments of different neurotrophic factors [157]. It has been tested in phase II clinical trials of moderate Alzheimer's disease.

\subsection{Administration of Neurotrophins by Injection}

Carrier-free administrations of BDNF (Table 1.I) have met little clinical success [47]. The first clinical trials have been performed with subcutaneous or intrathecal administrations of recombinant human BDNF in patients with amyotrophic lateral sclerosis (a motor neuron degenerative disease) [47]. This therapy has been well tolerated by patients, but it has lacked efficacy, due to the very short in vivo half-life of the therapeutic protein $(<2 \mathrm{~min})$ and its limited diffusion through the blood-brain barrier (BBB) [47]. For the treatment of Parkinson's disease, minipump systems have permitted a dosage control of glial cell-derived neurotrophic factor (GDNF) in the brain, but they have provoked tissue damage and side effects (cerebellar lesions, hallucinations, development of GDNF antibodies) $[119,139,159]$. A direct effect of GDNF on the dopamine storage capacity and function has been demonstrated [107].

Preclinical studies have been performed on rat models of induced cerebral ischemia, permitting the study of the protective effects of BDNF with intraventricular pretreatment or arterial venous treatments $[154,155,164]$. Intravenous treatment with BDNF has significantly reduced the infarct size. The observed neuroprotection has been related to BDNF-dependent downregulation of the pro-apoptotic protein, Bax, and upregulated expression of the anti-apoptotic protein, Bcl-2, in neurons in the ischemic penumbra. To study the influence of BDNF on long-term memory storage, a study has been performed using intrahippocampal neurotrophin injection in rats [11]. BDNF delivery has compensated the inhibited hippocampal protein synthesis and has induced memory persistence through ERK-signaling. On the other hand, BDNF administration via cochlear implants of osmotic mini-pumps has shown prolonged effects throughout deafness treatment in guinea pigs, even after two weeks of the discontinued infusion [88]. Owing to the fact that the in vivo half-life of the protein in the CNS is short, as a result of high turnover of the cerebrospinal fluid, the possibilities for neurotrophin diffusion to target cells have been limited [47,139]. Therefore, other approaches have searched for effective delivery of optimal BDNF doses.

\subsection{Neurotrophin Gene and Cell Therapy}

Local delivery of neurotrophins to neurons has been performed by gene therapy $[12,32,41,118,140,161,184-206,217]$. This method avoids the protein instability in circulation and may yield a lasting expression of BDNF [2]. Neurotrophin gene therapy (Table 1.II) has given 
encouraging pre-clinical results in studies of Huntington's disease and multiple sclerosis with rodents [12,194,197,200]. The intrastriatal injection of BDNF-encoding adenovirus has been established to be neuroprotective in an animal model $[12,194]$. Regulation of the locally produced neurotrophin levels has been achieved by intranigral implants secreting the protein [161]. In addition, a clinical trial for gene therapy of Alzheimer's disease has been performed with ex vivo transfected fibroblasts using viral vectors encoding for the human NGF gene [203]. The gene delivery system has been a graft of autologous fibroblasts genetically modified to express human NGF into the forebrain. Lentivirus and adenovirus types of vectors have been used for the transfer of NGF and NT-3 encoding genes in rat models of spinal cord injury [41,118,165,199,217]. Viral vectors, inducing long-lasting expression of neurotrophin molecules, have been studied in a rat model of epilepsy [140], whereas lentivirus systems, secreting BDNF, have been applied to models of Alzheimer's disease in rodents and primates [32]. Increased neurogenesis and broad neuroprotective effects have been observed $[32,41,165]$. The toxicity and inflammation caused by certain viral vectors, the risk of accidental tumor formation by mutagenesis and the invasive approach of this method have created challenges for its long-term clinical application with patients [1].

To avoid viral delivery of BDNF into the brain, alternative therapeutic strategies have been proposed for transplantation of cells releasing the neurotrophin [188,196,225]. Bone marrow stem cell (BMSCs)-based BDNF gene delivery into the CNS has shown a therapeutic effect on the reduction of the severity of disease by decreasing inflammation and enhancing immunomodulation and remyelination [197]. TrkB receptors have been activated by BDNF released by human mesenchymal stem cells (hMSC) implanted intranigrally to regulate neurotrophin expression [161] with a potential application in Parkinson's disease therapy. It should be stressed that these methods present a risk of rejection and can cause accidental tumor growth. Another approach for treatment of CNS lesions has employed non-viral vectors for transfer of genes encoding for BDNF and NGF [195].

Table 1. Summary of therapeutic strategies for treatment with neurotrophins ${ }^{a}$.

\begin{tabular}{|c|c|c|c|c|c|}
\hline Therapeutic strategy & Neurotrophin & Application & Model & Outcome & Refs. \\
\hline \multicolumn{6}{|c|}{ I. Administration of recombinant proteins by direct injection } \\
\hline $\begin{array}{c}\text { Subcutaneous and intrathecal } \\
\text { injection }\end{array}$ & BDNF & $\begin{array}{l}\text { Amyotrophic lateral } \\
\text { sclerosis (ALS) }\end{array}$ & $\begin{array}{l}\text { clinical trial } \\
\text { phase III }\end{array}$ & $\begin{array}{l}\text { limited BDNF diffusion through the } \\
\text { BBB; high dose required to observe } \\
\text { survival effects }\end{array}$ & {$[47]$} \\
\hline $\begin{array}{l}\text { Intracerebroventricular infusion } \\
\text { via implanted catheters }\end{array}$ & GDNF & Parkinson's disease & $\begin{array}{l}\text { clinical trials } \\
\text { phase I }\end{array}$ & $\begin{array}{c}\text { GDNF did not reach substantia nigra; } \\
\text { side effects }\end{array}$ & {$[119,139]$} \\
\hline $\begin{array}{l}\text { Direct intraputamenal perfusion } \\
\text { via implanted mini-pumps }\end{array}$ & GDNF & Parkinson's disease & $\begin{array}{l}\text { clinical trials } \\
\text { phase I and } \\
\text { phase II }\end{array}$ & $\begin{array}{c}\text { clinical improvement of symptoms after } \\
1 \text { year of therapy; GDNF effect on } \\
\text { dopamine function }\end{array}$ & $\begin{array}{l}{[107,124,} \\
159]\end{array}$ \\
\hline Intraventricular pretreatment & BDNF & Cerebral ischemia & rat & reduced infarct size & {$[154]$} \\
\hline Intraventricular infusion pumps & $\mathrm{BDNF}$ & $\begin{array}{l}\text { Cerebral venous } \\
\text { ischemia }\end{array}$ & rat & $\begin{array}{l}\text { reduced infarct size; protection of } \\
\text { cerebral cortex against apoptosis }\end{array}$ & [164] \\
\hline Intravenous & BDNF & Cerebral ischemia & rat & reduced infarct volume & {$[155]$} \\
\hline Mini-pump in the cerebral artery & BDNF & Cerebral ischemia & rat & reduced infarct size & {$[178]$} \\
\hline Intra-hippocampal injection & BDNF & $\begin{array}{l}\text { Long-term memory } \\
\text { (LTM) storage }\end{array}$ & rat & memory persistence & {$[11]$} \\
\hline
\end{tabular}


Table 1. Cont.

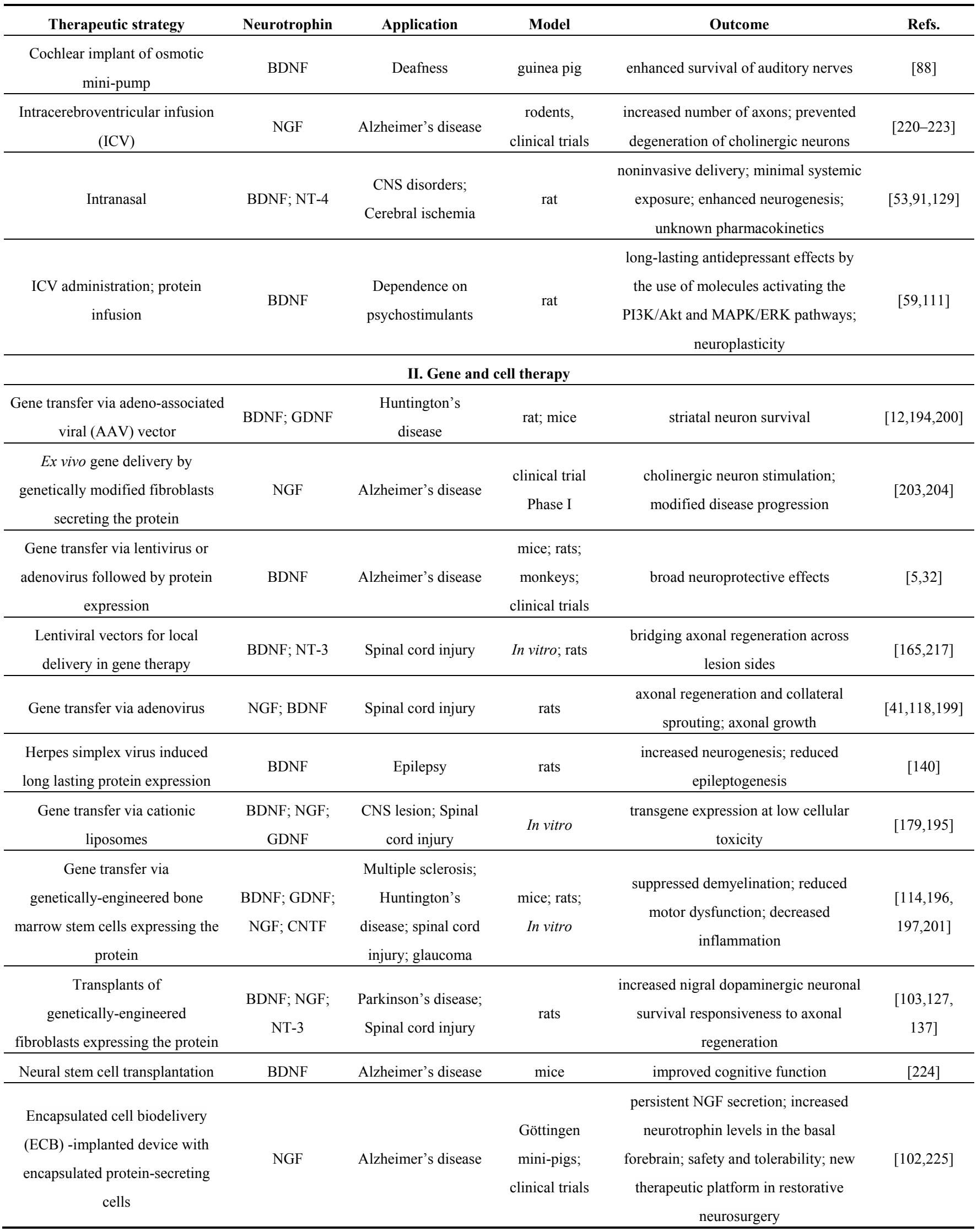


Table 1. Cont.

\begin{tabular}{|c|c|c|c|c|c|}
\hline Therapeutic strategy & Neurotrophin & Application & Model & Outcome & Refs. \\
\hline $\begin{array}{l}\text { Ex vivo gene therapy via } \\
\text { protein-expressing BHK cells } \\
\text { encapsulated in a device with a } \\
\text { semi-permeable polymer membrane }\end{array}$ & CNTF & $\begin{array}{l}\text { Huntington's } \\
\text { disease }\end{array}$ & $\begin{array}{c}\text { clinical trial } \\
\text { Phase I }\end{array}$ & $\begin{array}{l}\text { proof of principle for implanted } \\
\text { capsules }\end{array}$ & {$[184,188]$} \\
\hline $\begin{array}{l}\text { Intranigral transplants of mesenchymal } \\
\text { stem cells secreting the protein }\end{array}$ & BDNF & $\begin{array}{l}\text { Parkinson's } \\
\text { disease }\end{array}$ & in vitro; rats & $\begin{array}{l}\text { regulated BDNF expression and } \\
\text { dopaminergic effect }\end{array}$ & {$[161]$} \\
\hline \multicolumn{6}{|c|}{ III. Sustained release using polymer systems III.A. Synthetic polymers } \\
\hline $\begin{array}{l}\text { Polyethylene glycol (PEG) chain } \\
\text { conjugated at the } C \text {-terminus of the } \\
\text { recombinant protein (intravenous } \\
\text { administration) }\end{array}$ & BDNF & unspecified & in vitro; rats & $\begin{array}{l}\text { retained bioactivity of PEGylated } \\
\text { neurotrophin }\end{array}$ & [149] \\
\hline $\begin{array}{l}\text { Conjugation of a PEG chain and an } \\
\text { OX26 antibody (biotin/SA) for } \\
\text { targeted delivery (intravenous } \\
\text { administration) }\end{array}$ & $\mathrm{BDNF}$ & $\begin{array}{l}\text { Cerebral } \\
\text { ischemia }\end{array}$ & in vitro; rats & $\begin{array}{l}\text { increased brain uptake of the } \\
\text { BDNF construct; minimized rapid } \\
\text { clearance upon PEGylation }\end{array}$ & {$[141,175,183]$} \\
\hline $\begin{array}{l}\text { Covalent coupling with PEG chains } \\
\text { (intrathecal injection) }\end{array}$ & BDNF & $\begin{array}{l}\text { Spinal cord } \\
\text { injury and } \\
\text { diseases }\end{array}$ & in vitro; rats & $\begin{array}{l}\text { improved half-life in the } \\
\text { cerebrospinal fluid; increased } \\
\text { effect on locomotor activity }\end{array}$ & {$[89,160]$} \\
\hline $\begin{array}{l}\text { PLGA-PLL-PEG biodegradable } \\
\text { microspheres releasing recombinant } \\
\text { protein } \\
\end{array}$ & BDNF & CNS injury & in vitro & $\begin{array}{l}\text { sustained release of bioactive } \\
\text { human BDNF over } 60 \text { days }\end{array}$ & [94] \\
\hline $\begin{array}{l}\text { Poly(lactic-co-glycolic acid) (PLGA) } \\
\text { microspheres releasing recombinant } \\
\text { protein }\end{array}$ & NGF & $\begin{array}{l}\text { Huntington's } \\
\text { disease; } \\
\text { unspecified } \\
\text { lesions }\end{array}$ & $\begin{array}{l}\text { rats; } \\
\text { in vitro }\end{array}$ & $\begin{array}{l}\text { sustained release over } 2.5 \text { months; } \\
\text { improved protein stability; } \\
\text { reduced striatal lesions }\end{array}$ & {$[123,134,143]$} \\
\hline $\begin{array}{l}\text { PLGA biodegradable microspheres } \\
\text { releasing recombinant protein }\end{array}$ & GDNF & $\begin{array}{l}\text { Parkinson's } \\
\text { disease }\end{array}$ & $\begin{array}{l}\text { in vitro; rats; } \\
\text { monkeys }\end{array}$ & $\begin{array}{l}\text { improved dopaminergic graft } \\
\text { survival and function }\end{array}$ & $\begin{array}{r}{[90,98} \\
104-107 \\
115,116]\end{array}$ \\
\hline $\begin{array}{l}\text { Ethylene-co-vinyl acetate (EVAc) } \\
\text { discs for sustained release }\end{array}$ & NGF & $\begin{array}{c}\text { Alzheimer's } \\
\text { disease }\end{array}$ & in vitro; rats & $\begin{array}{l}\text { controlled release for up to one } \\
\text { week; limited NGF transport in } \\
\text { the brain tissue; high } \\
\text { concentrations near the implant }\end{array}$ & {$[121]$} \\
\hline EVAc discs and PLGA microspheres & NGF & $\begin{array}{l}\text { unspecified } \\
\text { CNS disease }\end{array}$ & in vitro; rats & $\begin{array}{c}\text { high localized doses of } \\
\text { recombinant protein near the } \\
\text { implants; half-life increased to } 1.7 \\
\text { hours }\end{array}$ & [153] \\
\hline
\end{tabular}


Table 1. Cont.

\begin{tabular}{|c|c|c|c|c|c|}
\hline Therapeutic strategy & $\begin{array}{l}\text { Neurotrop } \\
\text { hin }\end{array}$ & Application & Model & Outcome & Refs. \\
\hline PLA-PEG hydrogel & $\begin{array}{l}\text { BDNF; NT- } \\
\text { 3; NGF }\end{array}$ & $\begin{array}{l}\text { Spinal cord or } \\
\text { optic nerve } \\
\text { injury }\end{array}$ & $\begin{array}{l}\text { in vitro; } \\
\text { mice; rats }\end{array}$ & $\begin{array}{c}\text { sustained release over } 2 \text { weeks; } \\
\text { simultaneous delivery of multiple } \\
\text { neurotrophins; stimulated proliferation; } \\
\text { enhanced neurite outgrowth }\end{array}$ & {$[97,145,173]$} \\
\hline $\begin{array}{l}\text { Polyphosphoester (PPE) } \\
\text { microspheres incorporated in } \\
\text { nerve guide conduits }\end{array}$ & NGF & Nerve injury & rats & $\begin{array}{l}\text { morphological regeneration of sciatic nerve } \\
3 \text { months after the implantation of the } \\
\text { conduits }\end{array}$ & {$[177]$} \\
\hline $\begin{array}{l}\text { Ethylene-vinyl acetate (EVA) } \\
\text { nerve guidance channels } \\
\text { releasing the protein } \\
\end{array}$ & $\begin{array}{l}\text { GDNF; } \\
\text { NGF; NT- } \\
\text { 3; BDNF }\end{array}$ & $\begin{array}{l}\text { Sciatic nerve } \\
\text { injury }\end{array}$ & in vitro; rats & promoted regeneration of myelinated axons & {$[92,96,101]$} \\
\hline $\begin{array}{l}\text { Poly(lactide-co-glycolide) } \\
\text { (PLG) microspheres in nerve } \\
\text { guide conduits }\end{array}$ & NGF & $\begin{array}{l}\text { Spinal cord and } \\
\text { peripheral } \\
\text { nerve injury }\end{array}$ & $\begin{array}{l}\text { in vitro; } \\
\text { mice }\end{array}$ & $\begin{array}{l}\text { sustained release over } 42 \text { days from the } \\
\text { porous constructs allowing for cellular } \\
\text { infiltration into the channels; stimulated } \\
\text { neurite outgrowth }\end{array}$ & {$[180]$} \\
\hline PLA tubular macroporous foam & BDNF & $\begin{array}{l}\text { Spinal cord } \\
\text { injury }\end{array}$ & in vitro; rats & $\begin{array}{l}\text { low axonal regeneration response; increased } \\
\text { angiogenesis }\end{array}$ & [142] \\
\hline $\begin{array}{l}\text { Macroporous scaffold of } \\
\text { pHEMA and PLL }\end{array}$ & NGF; NT-3 & Nerve injury & in vitro & $\begin{array}{l}\text { minimum concentration gradient of } \\
200 \mathrm{ng} / \mathrm{mL} \text { required for guidance of the } \\
\text { neurite outgrowth }\end{array}$ & [136] \\
\hline $\begin{array}{l}\text { Conducting polypyrrole } \\
\text { scaffold with } \\
\text { surface-conjugated proteins }\end{array}$ & NGF; NT-3 & Nerve injury & in vitro; rats & $\begin{array}{l}\text { nerve fiber growth towards the implant } \\
\text { electrode }\end{array}$ & {$[108,146,169]$} \\
\hline Implanted EVAc matrices & BDNF & $\begin{array}{l}\text { Major } \\
\text { depression }\end{array}$ & rats & $\begin{array}{l}\text { dysregulation of BDNF-associated } \\
\text { plasticity-related pathways upon sustained } \\
\text { release; antidepressant-like effects upon } \\
\text { short-term delivery }\end{array}$ & [158] \\
\hline \multicolumn{6}{|c|}{ III.B. Naturally occurring polymers } \\
\hline Alginate microspheres & $\begin{array}{l}\text { NGF; } \\
\text { BDNF }\end{array}$ & $\begin{array}{l}\text { Brain injury; } \\
\text { major } \\
\text { depression }\end{array}$ & rats & $\begin{array}{c}\text { prevented neuronal degeneration; release } \\
\text { over 1-2 days; antidepressant-like } \\
\text { behavioral effects of BDNF }\end{array}$ & {$[132,158]$} \\
\hline Agarose hydrogels & BDNF & $\begin{array}{l}\text { Spinal cord } \\
\text { injury }\end{array}$ & rats & $\begin{array}{l}\text { encouraged neurite growth into the } \\
\text { channels; axonal regeneration; } \\
\text { minimal inflammatory response }\end{array}$ & {$[113,163]$} \\
\hline $\begin{array}{l}\text { Protein bound to collagen in } \\
\text { linearly ordered collagen } \\
\text { scaffolds (LOCS) }\end{array}$ & BDNF & $\begin{array}{l}\text { Spinal cord } \\
\text { injury }\end{array}$ & $\begin{array}{l}\text { in vitro; } \\
\text { rats }\end{array}$ & $\begin{array}{l}\text { improved neuron survival and recovery of } \\
\text { spinal cord injury }\end{array}$ & {$[110]$} \\
\hline $\begin{array}{l}\text { Hyaluronic-acid hydrogel } \\
\text { scaffold }\end{array}$ & BDNF & $\begin{array}{l}\text { Spinal cord } \\
\text { injury }\end{array}$ & in vitro; rats & $\begin{array}{c}\text { regeneration; improvement in locomotive } \\
\text { tests }\end{array}$ & {$[218]$} \\
\hline $\begin{array}{l}\text { Agarose hydrogel coupled with } \\
\text { laminin } \\
\end{array}$ & NGF & Nerve injury & in vitro & enhanced neurite extension & {$[182]$} \\
\hline Collagen matrix implants & NT-3 & $\begin{array}{l}\text { Spinal cord } \\
\text { injury }\end{array}$ & rats & $\begin{array}{l}\text { attraction of corticospinal tract fibers into } \\
\text { the graft; recovery function }\end{array}$ & [112] \\
\hline
\end{tabular}


Table 1. Cont.

\begin{tabular}{|c|c|c|c|c|c|}
\hline Therapeutic strategy & Neurotrophin & Application & Model & Outcome & Refs. \\
\hline Fibrin matrix containing & & & & enhanced nerve regeneration across short & \\
\hline $\begin{array}{l}\text { heparin (or peptide) } \\
\text { bound via electrostatic } \\
\text { interactions to }\end{array}$ & $\begin{array}{l}\text { BDNF; NGF; } \\
\text { NT-3 }\end{array}$ & $\begin{array}{l}\text { Unspecified; } \\
\text { Spinal cord injury; } \\
\text { Sciatic nerve injury }\end{array}$ & in vitro; rats & $\begin{array}{l}\text { nerve gaps; localized controlled release up } \\
\text { to } 7 \text { days; dose-dependent axonal } \\
\text { regeneration; affinity-based delivery }\end{array}$ & $\begin{array}{l}{[126,131,150,} \\
166,167,171]\end{array}$ \\
\hline recombinant protein & & & & systems for neural tissue engineering & \\
\hline \multicolumn{6}{|c|}{ IV. Lipids and diets variations } \\
\hline $\begin{array}{l}\text { Caloric restriction; } \\
\text { physical exercise }\end{array}$ & BDNF; GDNF & Parkinson's disease & $\begin{array}{l}\text { Rhesus } \\
\text { monkeys }\end{array}$ & $\begin{array}{l}\text { higher locomotor activity; increased } \\
\text { neuronal survival in substantia nigra and } \\
\text { striatum }\end{array}$ & {$[125,130]$} \\
\hline $\begin{array}{l}\text { Potentiation by omega-3 } \\
\text { fatty acid }\end{array}$ & BDNF & $\begin{array}{l}\text { cellular model of } \\
\text { neurodegeneration }\end{array}$ & in vitro & increased cell survival & {$[219]$} \\
\hline $\begin{array}{c}\text { Triglyceride matrix } \\
\text { implants } \\
\end{array}$ & $\begin{array}{l}\text { BDNF (lysozyme } \\
\text { model) }\end{array}$ & $\begin{array}{c}\text { Huntington's } \\
\text { disease } \\
\end{array}$ & in vitro; rats & $\begin{array}{l}\text { controlled release over } 1-2 \text { months; } \\
\text { preserved protein activity and integrity }\end{array}$ & {$[120]$} \\
\hline \multicolumn{6}{|c|}{ V. Peptidomimetics, small molecule mimetics and prodrugs } \\
\hline Peptidomimetics & BDNF & $\begin{array}{c}\text { Neurodegenerative } \\
\text { disorders } \\
\end{array}$ & in vitro & $\begin{array}{c}\text { BDNF-like agonist action; sensory } \\
\text { neurons survival } \\
\end{array}$ & {$[207-211]$} \\
\hline $\begin{array}{l}\text { Small molecule mimetics } \\
\text { and modulators }\end{array}$ & BDNF & $\begin{array}{l}\text { Motor trauma; } \\
\text { Alzheimer's disease }\end{array}$ & $\begin{array}{l}\text { rodents; } \\
\text { in vitro }\end{array}$ & $\begin{array}{l}\text { TrkB agonists; modulation of the activity } \\
\text { of the TrkB receptor; improved motor } \\
\text { learning; promoted neurogenesis }\end{array}$ & {$[212-216]$} \\
\hline $\begin{array}{c}\text { Prodrugs of } \\
\text { non-peptide neurotrophin } \\
\text { mimetics } \\
\end{array}$ & $\begin{array}{l}\text { non-peptide } \\
\text { mimetics of } \\
\text { BDNF }\end{array}$ & $\begin{array}{l}\text { Psychiatric } \\
\text { disorders }\end{array}$ & Mice & $\begin{array}{l}\text { reduced depression- and anxiety-related } \\
\text { behaviors; blood-brain barrier penetration }\end{array}$ & {$[213,215]$} \\
\hline Peptidomimetics & NT-3 & $\begin{array}{c}\text { Peripheral } \\
\text { neuropathies; } \\
\text { neurodegenerative } \\
\text { diseases }\end{array}$ & $\begin{array}{l}\text { in vitro; } \\
\text { animal models }\end{array}$ & $\begin{array}{l}\text { selective inhibition of TrkC-mediated cell } \\
\text { survival; neuroprotection }\end{array}$ & {$[226-228]$} \\
\hline
\end{tabular}

${ }^{a}$ BDNF: brain-derived neurotrophic factor; GDNF: glial cell line-derived neurotrophic factor; NGF: nerve growth factor; CNTF: ciliary neurotrophic factor; NT-3: neurotrophin-3.

\subsection{Sustained Release of Neurotrophic Factors by Means of Polymer Carriers}

Synthetic and natural polymers are suitable for controlled delivery of neuroprotective molecules to therapeutic targets (Table 1.III). Several studies have attempted to realize sustained release of neurotrophins to brain using a variety of polymers [90-144,180-183].

\subsubsection{Synthetic Polymers}

One of the first polymeric formulations, designed for intracerebral implants releasing NGF, has employed the nondegradable polymer poly(ethylene co-vinyl acetate) (EVAc) [121]. Some years later, delivery systems have been fabricated from EVAc discs and poly(lactic-co-glycolic acid) (PLGA) biodegradable microspheres and have been compared in in vitro and in vivo studies in rats [153]. The controlled delivery of NGF from intracerebral implants, built-up from PLGA microspheres, has been extensively studied in vitro and in vivo [123,134,143]. Higher local concentrations of recombinant 
protein have been observed near the implants. Controlled local release of GDNF from biodegradable PLGA microspheres has been realized with rats subjected to brain stereotaxy for local intracranial microspheres implantation [90,98,104-106,115,116]. The comparison of different delivery systems has indicated distinct patterns of recombinant protein (rhNGF) release in rats (for $10 \mathrm{mg}$ intracranial implants), i.e., (i) sustained release from ethylene-co-vinyl acetate (EVAc) discs, (ii) immediate release from poly(lactic-co-glycolic acid) (PLGA) microspheres prepared by double emulsion/solvent evaporation and (iii) delayed release from PLGA microspheres prepared by spray freeze-drying. The latter system has provided the highest release rate. The diffusion coefficient of rhNGF through the brain tissue $\left(8 \times 10^{-7} \mathrm{~cm}^{2} / \mathrm{s}\right)$ has been evaluated to be $\sim 50 \%$ of the diffusion coefficient in water solution. The achieved rates of rhNGF release, greater than $100 \mathrm{ng}$ per day, have been appropriate for treating animal models of Alzheimer's disease [153].

Biodegradable microspheres of the triblock polymer PLGA-polylysine-polyethylene glycol (PLGA-PLL-PEG) have provided sustained release of BDNF during 60 days of in vitro assays [94]. The encapsulated BDNF has preserved its bioactivity. The PLGA-PLL-PEG microspheres have yielded greater loading and longer-term delivery of BDNF, as compared to the PLGA ones. It has been suggested that this amphiphilic polymer increases the interaction of the neurotrophin with the carrier and leads to sustained release that closely correlates with the polymer degradation [94]. On the other side, special hyaluronan (HA) and methylcellulose (MC) hydrogels, containing PLGA particles releasing six different neuroprotective proteins, have been administered by intrathecal injections [95]. Biodegradable hydrogels formed by the copolymer of polylactic acid (PLA) and polyethylene glycol (PLA-PEG) have also been studied as neurotrophin carriers [97,145,173]. The outcomes of these studies with animal models are summarized in Table 1.III.

Microspheres of polyphosphoester (PPE), containing NGF, have been transferred into synthetic nerve guidance conduits allowing for sustained neurotrophin delivery and regeneration of damaged neurons [177]. Nerve guide channels have been synthesized from EVAc as well [92,96,101]. Copolymers of lactic and glycolic acids (PLG) have served for the construction of nerve conduits releasing neurotrophin [180]. Macroporous foams of PLA have been used as brain implants for local release of BDNF [142]. Scaffolds of polyhydroxyethyl (pHEMA) and polylysine (PLL) have ensured defined concentration gradients of NGF and NT-3 [136]. Work has been done also on coupling of neurotrophins on the surface of the biocompatible polymer polypyrrole, which has electric conductive properties $[108,146,169]$. The advantage of the polymer materials implanted into the CNS (PLG, PLA, PLL, EVAc, pHEMA, PPE) is their biocompatibility. The nature of the polymers influences the adsorption of proteins and the extent of adhesion of inflammatory cells on the implants. The shape and the surface area of the implants (microspheres with high surface area versus large-sized conduits with small material/tissue interfaces) also determine the inflammatory response. Brain tissue reactions to the scaffolds implantation have often involved acute inflammatory response within the first week in relation to the mechanical damage to the $\mathrm{CNS}$, rather than to the nature of the polymer material.

The PEGylation of the $C$-terminus of BDNF, via conjugation of a polyethylene glycol (PEG) chain, has been efficient in reduction of the systemic clearance of the neurotrophin and has resulted in minimal loss of its biological activity [149]. BDNF, covalently conjugated to one or more PEG chains, has also preserved its biological activity with enhanced distribution in the spinal cord [160]. In affinity-based systems, the biotinylation of the PEG terminus of the PEG-modified neurotrophin has 
served for its coupling to the anti-transferrin monoclonal antibody OX26 (MAb OX26) through an anchored streptavidin (SA). The created protein construct has allowed for activation of the transferrin receptor, which is abundantly present in the brain capillary endothelium. The BDNF-PEG-MAb-OX26/SA conjugate has been employed for BDNF targeting to brain after intravenous administration $[141,175,183]$. The transferrin receptor has mediated its transport through the BBB. It should be noted that the capacity of this system for BDNF delivery has been generally low, because every therapeutic protein molecule (BDNF) requires as a vector, in this receptor-mediated delivery approach, a bound monoclonal antibody molecule (OX26) (i.e., one carrier entity can transport only one therapeutic molecule). At variance, Trojan horse liposomes [231,232], coupled with Mab OX26, can encapsulate several neurotrophin molecules in their aqueous reservoirs. This augments the delivery capacity of the system, as every carrier can transport many BDNF molecules.

\subsubsection{Natural Polymers}

Owing to its biocompatibility, biodegradability, low toxicity and hydrophobicity, alginate has been used in the form of microspheres to provide sustained release of the neurotrophin NGF [132]. Porous hydrogels of agarose have been employed for construction of scaffolds for controlled release of BDNF and NGF [113,163]. Biocompatible agarose gel scaffolds, coupled with different laminin oligopeptides, have promoted an enhanced neurite growth [181,182]. Collagen has also been a good matrix for sustained local release of neurotrophins [112]. Matrices involving fibrin derivatives and heparin-binding peptides, coupled to neurotrophins, have been extensively studied in vitro and in vivo $[126,131,151-153,166,168,171]$. The in vitro neurite growth, observed upon controlled protein release, has been considerable with these systems. Sciatic nerve regeneration has been achieved in vivo in a rat model of spinal cord injury $[166,168,171]$. The results obtained with fibrin matrices have indicated the role of the neurotrophin carrier serving as a therapeutic material to enhance peripheral nerve regeneration through nerve guide tubes. It has been demonstrated that BDNF, NGF and NT-3, interacting with fibrin matrices containing a large molar excess of heparin relative to the neurotrophic growth factor, may enhance neurite extension by up to $100 \%$ relative to unmodified fibrin [150]. At variance, free neurotrophins have not enhanced neurite extension in the absence of a delivery system. For the release characteristics of the natural polymer biomaterials, as biodegradable compounds of different kinetics of degradation in the tissues, the reader is referred to the cited references.

\subsection{Dietary Restrictions}

Preclinical studies have shown that dietary restrictions and physical exercise may increase the BDNF levels [1]. In this way, multiple pathways and molecular mechanisms can be activated, permitting correction of the deficiency of neurotrophic factors. It has been reported that a low-calorie diet can attenuate the severity of neurochemical deficits and motor dysfunction in a primate model of Parkinson's disease [130]. Understanding of the relationship between diet, energy intake and BDNF levels may thus lead to new therapeutic approaches [125,130]. For example, physical exercise has induced BNDF expression in several brain regions and has reduced the neuronal damage $[1,130]$. 


\subsection{Peptide Mimetics of BDNF}

Increased endogenous BDNF levels and neuroprotection can be achieved by small medicinal drugs $[212,213,215,216]$. The observed effects have generally been nonspecific. As an alternative, an emerging therapy with synthetic peptide mimetics of BDNF may offer high selectivity and specificity for the disease mechanisms. Notably, peptidomimetics can be resistant to degradative enzymes. This aspect helps in increasing the stability of the peptidomimetic drugs and their bioavailability [229].

The peptidomimetics approach considers the three-dimensional (3D) structure of BDNF used for identification and modeling of the loops participating in binding to the TrkB receptor and its activation [207-211]. Towards that aim, the biological functions of the BDNF loops (Figure 1) have been examined. Site-directed mutagenesis analysis has revealed that the ability to bind and activate the TrkB receptor may be conferred by replacement of selected amino acid residues in loop 2 of NGF with those corresponding to BDNF [69]. Having in mind the established receptor-binding roles of loops 1, 2 and 4 of BDNF, mono- and bi-cyclic peptide mimetics of BDNF have been synthesized, including homodimers of the loops 2 and 4 [207]. The homodimeric bicyclic mimic of loop 4 of BDNF has been less efficient, as compared to the homodimer mimic of loop 2 (Figure 3).

Figure 3. Design of peptide mimetic dimers of neurotrophic factors based on the structure of the loop 2 in heterodimer configurations BDNF/NGF (left and middle) and in a BDNF homodimer (right). The cysteine bridges and the interloop distances are indicated.
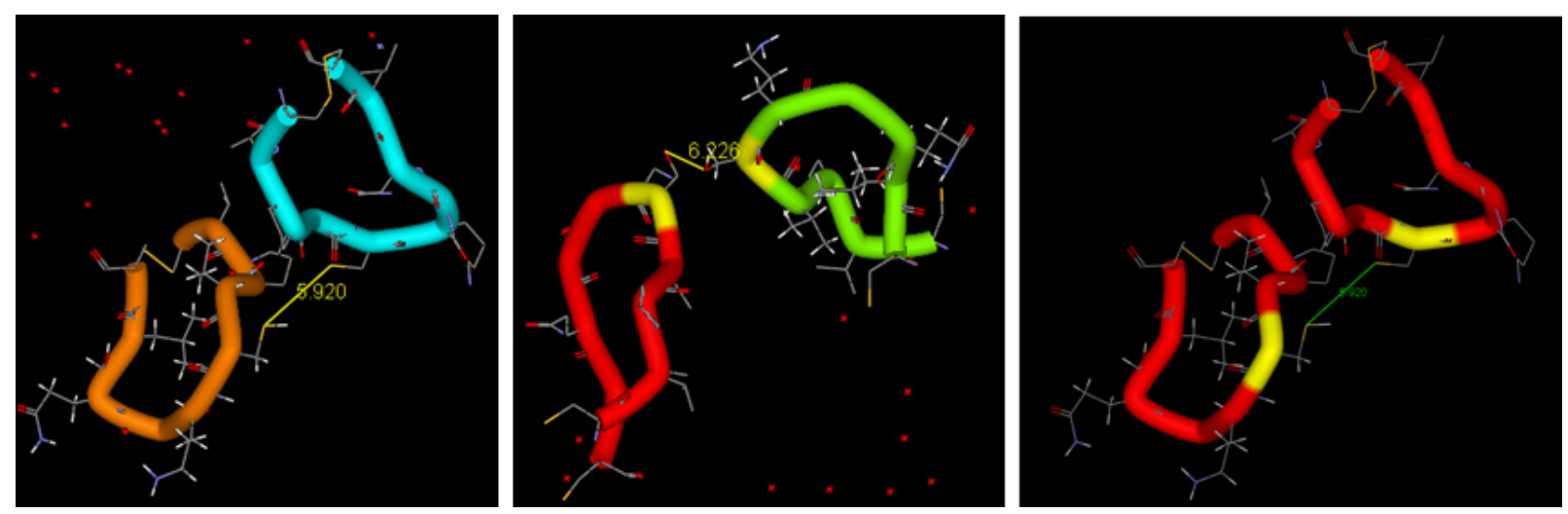

By comparison of the biological activities of designed cyclic peptide dimers with various compositions, mimicking the loops 1, 2 or 4 of BDNF, it has been concluded that the BDNF-like partial agonist activity should be related to the ability of the new compounds to dimerize the TrkB receptor in a manner similar to the native neurotrophic factor (Figure 2). Preliminary studies have shown that the designed BDNF peptidomimetics can act as BDNF agonists, promote neurite outgrowth and support the survival of sensory neurons [207,211]. In fact, peptides with conformational constraints, mimicking loop 2 of BDNF, have inhibited the neurotrophin-mediated survival of sensory neurons in culture, presumably by exerting a competitive TrkB antagonist action [210].

\section{Soft Nanotechnologies and Nanocarrier-Mediated Delivery}

Soft nanotechnology refers to design, engineering and manipulation of soft materials towards the creation of structures (such as nanoparticle objects as drug carriers) and devices of a nanometer-length 
scale. The majority of known nanoparticulate systems for drug delivery and targeting to the CNS [230,233-241] have not been exploited for neurotrophin delivery yet. A variety of nanocarriers, such as dendrimers, nanospheres, solid lipid nanoparticles (SLN), nanoemulsions, polymeric micelles, multifunctional nanoparticles (NPs) and nanoscale systems for imaging [242-246], are expected to be studied for controlled release of neurotrophins. Nanoparticulate systems for growth factor delivery have attracted increasing recent interest [122,176,219,231,232,246-259].

In searching for innovative therapeutic approaches to treat neurodegenerative disorders, colloidal nanoparticle carriers have been designed as reservoirs for neurotrophins, ensuring their protection against enzymatic degradation and other destructive stressor factors. Indeed, the walls of the nanoparticulate containers (such as lipid membrane-type vehicles, nanocapsules and nanospheres) can completely isolate the therapeutic substances from the environment. Colloidal nanocarriers can be coated with hydrophilic polymers, such as polyethylene glycol (PEG), or with albumin in order to reduce their opsonization and increase their in vivo circulation time. Importantly, neurotrophin encapsulation in NPs may help locally administer a neuroprotective agent in a concentrated state to target sites, while minimizing eventual systemic side effects and toxicity. Another advantage of the NPs delivery systems is the possibility to combine different types of active molecules in one nanocarrier (for instance, neurotrophic drug molecules together with a diagnostic imaging agent for cerebral theranostics). Moreover, targeted delivery can be performed via modifying the surface of the nanocarriers by anchoring of specific ligands for receptor recognition [176,248].

Table 2 presents examples of neurotrophin delivery systems issued by soft nanotechnologies (nanocarriers prepared by "bottom-up" self-assembly or by "scaling-down" fragmentation of bulk soft materials), as well as by nanobiotechnology (nanocarriers based on fusion proteins produced via biotechnology techniques) [122,176,219,231,232,247-259].

Table 2. Nanoscale carrier systems for neurotrophin delivery.

\begin{tabular}{|c|c|c|c|}
\hline Nanosystem & Neurotrophin & Disease/Model & Reference \\
\hline $\begin{array}{l}\text { Polysorbate-coated poly(butyl } \\
\text { cyanoacrylate) (PBCA) NPs }\end{array}$ & NGF & Parkinson's disease/mouse & [122] \\
\hline $\begin{array}{c}\text { Nanoporous poly-L-glutamic acid } \\
\text { (PGA) particles }\end{array}$ & BDNF & Deafness/guinea pig, in vitro & {$[254]$} \\
\hline $\begin{array}{c}\text { Layer-by-layer (LbL) films on } \\
\text { agarose hydrogel scaffolds }\end{array}$ & BDNF (a lysozyme model) & Spinal cord injury/in vitro & [247] \\
\hline $\begin{array}{l}\text { Poly(ethylene glycol)-poly } \\
\text { ( } \varepsilon \text {-caprolactone) (PEG-PCL) } \\
\text { polymersomes conjugated with } \\
\text { OX26 MAb }\end{array}$ & $\begin{array}{l}\text { NC-1900 peptide (an arginine- } \\
\text { vasopressin fragment analogue) }\end{array}$ & $\begin{array}{l}\text { Learning and memory } \\
\text { impairments/rat }\end{array}$ & {$[248]$} \\
\hline $\begin{array}{c}\text { PEG-b-PCL polymersomes with } \\
\text { surface-attached polyethylene glycol } \\
\text { (PEG) chains }\end{array}$ & $\begin{array}{l}\text { NGF mimetic peptide (hNgfEE) } \\
\text { as an alternative of BDNF }\end{array}$ & In vitro & {$[255,256]$} \\
\hline Targeted liposomes & NGF & Alzheimer's disease/in vitro & [176] \\
\hline Immunoliposomes & $\begin{array}{l}\text { Model plasmids (luciferase, } \\
\beta \text {-galactosidase, SV40-lacZ) }\end{array}$ & $\begin{array}{c}\text { Brain disorders/rhesus } \\
\text { monkey }\end{array}$ & $\begin{array}{l}{[231,249,} \\
250,260]\end{array}$ \\
\hline
\end{tabular}


Table 2. Cont.

\begin{tabular}{cccc}
\hline Nanosystem & Neurotrophin & Disease/Model & Reference \\
\hline Cationic liposomes & $\begin{array}{c}\text { Plasmid encoding for GDNF or } \\
N G F\end{array}$ & $\begin{array}{c}\text { Spinal cord injury/in vitro } \\
{[179,195]}\end{array}$ \\
\hline $\begin{array}{c}\text { NTS (neurotensin)-polyplex } \\
\text { nanocarrier }\end{array}$ & $\begin{array}{c}\text { Peurotrophic genes } \\
(G D N F, N R T N, B D N F)\end{array}$ & $\begin{array}{c}\text { Parkinson's } \\
\text { disease/transfected } \\
\text { dopaminergic neurons } \\
\text { in vitro, rat }\end{array}$ & {$[205]$} \\
\hline PEGylated cationic lipid NPs & Plasmid encoding for $B D N F$ & In vitro & {$[257,258]$} \\
\hline $\begin{array}{c}\text { Cubosome NPs containing essential } \\
\text { omega-3 fatty acid }\end{array}$ & BDNF & In vitro & {$[219]$} \\
\hline Cubosome NPs & Neuroprotective peptide & Alzheimer's disease/rat & {$[259]$} \\
\hline Trojan horse nanocarriers & $\begin{array}{c}\text { GDNF; plasmid driven by } \\
\text { brain-specific promoter }\end{array}$ & $\begin{array}{c}\text { Parkinson's disease/rodents, } \\
\text { rhesus monkeys }\end{array}$ & {$[231,232$,} \\
Fusion protein vectors & BDNF-IgG (OX26); & $\begin{array}{c}\text { Ischemial stroke, Parkinson's } \\
\text { disease, Alzheimer's } \\
\text { disease/rats }\end{array}$ & {$[231$,} \\
\hline & NGF-IgG; GDNF-Tat & $249-253$, \\
& & $261]$ \\
\hline
\end{tabular}

Nanoparticles of poly(butyl cyanoacrylate), carrying NGF neurotrophin, have been characterized by enhanced penetration through the BBB after surface functionalization by polysorbate 80 [122]. BDNF has been encapsulated in nanoporous poly(L-glutamic acid) (PGA) particles, produced via mesoporous silica templating, from which it has been released in a sustained manner with retained biological activity on SH-SY5Y cells [254]. In vivo experiments have demonstrated that the released BDNF can efficiently rescue auditory neurons in the cochlea of guinea pigs with sensorineural hearing loss [254]. Another nanostructured system for sustained release of BDNF (using lysozyme as a model protein) has been fabricated by alternating assembly of poly(ethylene glycol)(PEG)/poly(acrylic acid)(PAA)/ protein layer-by-layer (LbL) thin films on agarose hydrogel template [247]. The achieved month-long sustained protein release from the agarose hydrogel scaffold has shown promise to promote axonal regeneration in the CNS after spinal cord injury.

A short peptide mimetic of NGF (with a sequence similar to BDNF) has been conjugated to the surface of polymersome nanoparticles and has been in vitro studied for TrkB receptor targeting on SHSY-G7 cells [255]. The PEGylated surface of the polymersomes has allowed for increased in vivo retention time of the carriers, which have acted as scaffolds for the delivery of TrkB-activating ligands. The TrkB receptor has been found to be phosphorylated when targeted by NGF-peptide-conjugated polymersomes, whereas no TrkB phosphorylation has been detected in SHSY-G7 cells incubated with unfunctionalized polymersomes [255]. This strategy may be classified as peptide-targeted nanocarriers to treat neurodegeneration. The synthetic neurotensin (NTS)-polyplex nanocarrier system has enabled delivery of neurotrophic genes to dopaminergic neurons via NTS receptor-mediated endocytosis mechanism of internalization [205].

In a recent work, Géral et al. [219] have shown the potentiation effect of multicompartment lipid carriers containing omega-3 polyunsaturated fatty acid, the eicosapentaenoic acid (EPA), on the BDNF activity in in vitro neuroprotective experiments with a SH-SY5Y cell line. The human neuroblastoma 
SH-SY5Y cells have been differentiated by retinoic acid, which has induced the expression of the TrkB receptor. The viability of the SH-SY5Y cells after five days of treatment with retinoic acid $(10 \mu \mathrm{M})$ has been estimated to be $44 \% \pm 6 \%$, as compared to untreated cells (100\% viability). This result has indicated an essential decrease in the cellular proliferation in the absence of neuroprotective treatment. By comparison of the relative cellular viability, determined in the presence of BDNF and multicompartment lipid NPs of a cubosome type, it has been established that the lipid composition of the nanovehicles can be very essential for neurogenesis [219]. The results have confirmed that the activity of BDNF is potentiated by the omega-3 fatty acid (EPA) rather than by the other lipids constituting the NPs. The percent of cell survival has increased almost three-times in the presence of EPA-containing NPs (at a total lipid concentration of $4.2 \times 10^{-8} \mathrm{M}$ ). Very long and branched neurites have been observed when the neuroblastoma cells have been treated with BDNF in the presence of lipid nanocarrier systems containing EPA (Figure 4). The polyunsaturated fatty acid, EPA, has shown a real effect of potentiation of the neurotrophic factor BDNF alone and in a combination with liquid crystalline monoolein (MO)-based multicompartment nanoassembles [219].

Immunoliposomes, i.e., PEGylated liposomes coupled with antibodies, such as the anti-transferrin monoclonal antibody (OX26 MAb), have been employed in receptor-mediated gene delivery to the brain through the transferrin receptor at the BBB [231,249,250]. PEGylated immunoliposomes have been in vivo targeted to the rhesus monkey brain with a monoclonal antibody to the human insulin receptor (HIR MAb) as well. The MAbs have enabled the liposomes to undergo transcytosis across the BBB and endocytosis across the neuronal plasma membrane following intravenous injection. This approach is related to the Trojan horse technology for neurotrophin targeting and release [231,232,245].

Figure 4. Phase contrast microscopy images of neurite outgrowth in differentiated, alive human neuroblastoma SH-SY5Y cells after neuroprotective treatment with $2 \mathrm{ng} / \mathrm{mL} \mathrm{BDNF}$ and lipid nanoparticles (MO/DOPE-PEG $2000 / E P A, 83 / 2 / 15$ mol\%) with a total lipid concentration of $4 \times 10^{-7} \mathrm{M}$ (left), as compared to untreated SH-SY5Y cells grown in culture medium (right). Image size: $270 \times 200 \mu \mathrm{m}^{2}$.
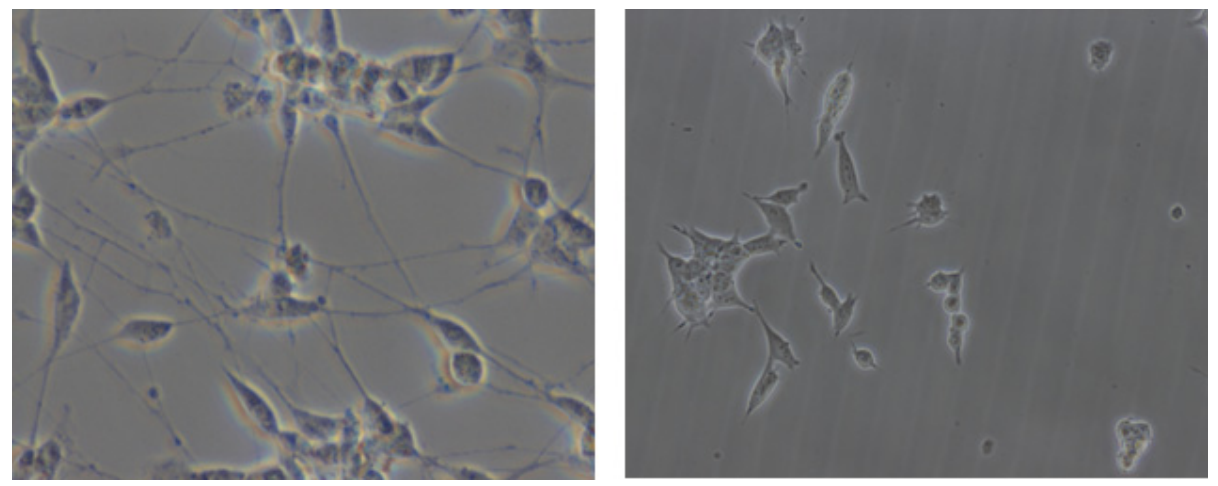

Receptor-mediated delivery of neurotrophins through the transferrin and insulin receptors has also been done by fusion proteins engineered for brain targeting [261,260]. The molecular Trojan horse technology involves genetically engineered chimeric complexes of neurotrophins (BDNF, NGF, GDNF) and human immunoglobulin (IgG) monoclonal antibodies recognizing the human transferrin or insulin receptors, which enable delivery across the BBB. The IgG fusion proteins have shown low 
immunogenicity in primates [252]. The BDNF-IgG fusion protein has demonstrated a significant neuroprotective effect against forebrain ischemic injury in rats after intravenous administration. This nanobiotechnology approach, which is alternative to the chemical conjugation strategies [141,183], has revealed a potential for clinical use in stimulation of brain repair in post-ischemic therapy [253].

Among the nanocarrier systems with controlled-release and biocompatibility properties, lipid nanoparticles [262] represent a very interesting way for neurotrophin administration, as well as for development of neuroregenerative therapeutics. To date, lipids of various types have been widely used for delivery of nanomedicines by different routes of administration. In the presence of an aqueous medium, amphiphilic lipids self-organize in compartmentalized structures with separated polar and apolar domains [262-292]. Hydrophobic interactions play a key role in stabilizing the nanostructures that form based on the existing lipid polymorphism [281]. Lipids can adopt different structural organizations, the most common ones being the lamellar bilayer, inverted cubic, inverted hexagonal, sponge and micellar phases. The diversity of the lipid/water structural arrangements is essential for the encapsulation capacity of the created carriers for therapeutic molecules [271].

Vesicles, liposomes, cubosomes, spongosomes and hexosome particles appear to be lipid-based vehicles suitable for peptide and protein encapsulation [282,289]. Such particles are biocompatible, biologically inert and show little toxicity and antigenic reactions. They can be prepared by hydration of a lipid film, followed by energy supply, for instance, mechanical vortexing and sonication. Upon agitation, the hydrated lipid sheets detach and self-assemble either in bilayer membrane-type liquid crystalline NPs or in lipid-monolayer-based structures (Figure 5). The diameter of the lipid vehicles can vary between $20 \mathrm{~nm}$ and several hundred microns. The stable, in vivo release of active molecules and biodistribution of the NPs are determined by their size, surface charge and lipid membrane fluidity. Sterically stabilized ("stealth") liquid crystalline lipid NPs can be obtained by PEGylation or by self-assembly with amphiphilic copolymers, forming stabilizing hydrophilic shells. This may help avoiding aggregation during storage or due to physico-chemical instability. Targeted-delivery strategies can be realized by attachment of specific monoclonal antibodies or ligands to the lipid NPs surfaces [292].

Vesicles and liposomes are lipid membrane-type particles composed of one or more phospholipid bilayers enclosing an aqueous volume (Figure 5). Lipophilic substances can be incorporated into the lipid bilayers, while hydrophilic compounds can be entrapped in the aqueous core. Thus, the aqueous compartments can be used for the encapsulation of neurotrophins.

Cubosomes and spongosomes are membrane-types of NPs with non-lamellar organizations. The cubosomes are characterized by periodically ordered cubic lattice membrane structures (of diverse symmetries, such as double diamond (D), gyroid (G) or primitive (P) cubic types), whereas spongosomes involve a random 3D membrane organization. Cubosome NPs have been considered to be more stable lipidic particulate systems, as compared to liposomes. In cubosome structures, the cubic lipid membrane subdivides the space into intertwined networks of aqueous channels. The enhanced capacity of these non-lamellar, multicompartment-type lipid vehicles for biomolecular drug encapsulation results from the liquid crystalline bicontinuous membrane architecture of the NPs. Compared to liposomes, the specific surface area developed by the lipid bilayer in non-lamellar-type lipid nanocarriers is much greater, thus increasing the possibilities for incorporation of guest molecules in cubosomes and spongosomes. These structures offer the opportunity to entrap neurotrophins in the 
water channels of the carriers, as well as for controlled release, through a slow diffusion process, from the nanochannelled assemblies. Cubosomes have been efficient in enhancement of the therapeutic protein stability against enzymatic degradation. Toward parenteral administration, colloidal dispersions of cubosome particles have been stabilized by the inclusion of an amphiphilic copolymer, such as Pluronic F127 [269,273]. Investigations on the interaction of cubosomes with plasma components in rats have shown a prolonged circulation of the particles [280]. On the other side, cubosomes have provided a new method for entrapment of protein molecules in lipid nanochannelled networks, leading to a new class of particles named "proteocubosomes" [265]. The proteocubosome carriers appear to be built up by assemblies of porous droplets ("nanocubosomes") with diameters between 30 and $60 \mathrm{~nm}$. Large protein molecules have been suggested to be confined at the interfaces between the nanocubosomes, inside the multicompartment proteocubosome particles.

Figure 5. Lipid nanoparticulate carriers produced by soft nanotechnology. The channels allowing for protein nanoencapsulation are organized on an inner hexagonal lattice in the hexosome lipid particles, whereas the cubosome lipid particles can have different inner channel symmetries, such as primitive (P) cubic (cubosome of P-type) and diamond (D) cubic lattices (cubosome of D-type).

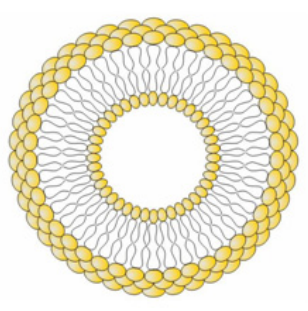

Liposome

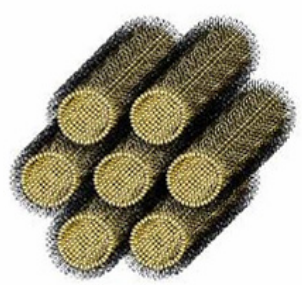

Hexosome

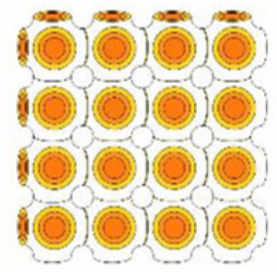

Cubosome (P)

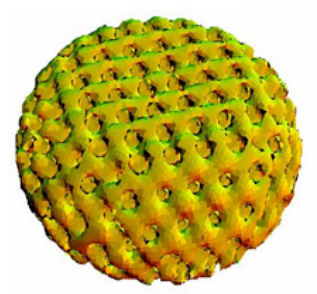

Cubosome (D)

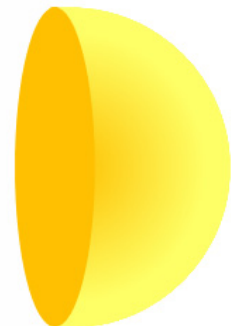

Nanosphere

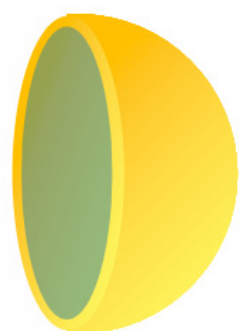

Nanocapsule

Cubosomes modified by odorranalectin (a novel non-immunogenic small peptide) have been prepared as nanovehicles with mucoadhesive properties providing enhanced drug delivery to the brain upon intranasal administration [259]. In this intranasal route for treatment of CNS disorders, Gly14-humanin has been loaded, as a model neuropeptide drug, in cubosomes and evaluated for its pharmacodynamics in Alzheimer's disease (AD) in rats. Based on the enhanced therapeutic effects found with the peptide-loaded cubosomes, the results have suggested that functionalized cubosomes represent a novel effective and non-invasive system for neurotrophic peptide transport [259].

Towards application in neurosurgery, triglyceride matrices have been examined for their biocompatibility and controlled release of BDNF [120]. In addition, concepts for novel lipid carriers 
for biomedical and diagnostic applications have been proposed, taking into account the ability of omega-3 polyunsaturated fatty acids (e.g., EPA) for neurotrophin potentiation [219].

Hexosomes are lipid NPs of inverted-hexagonal-phase inner arrangement of aqueous channels (Figure 5). The quantity of nanoencapsulated molecules in such carriers can be controlled via the diameter of the inner aqueous channels. The high surface-to-volume ratio appears to be advantageous for interaction of these NPs with cells. They have found applications as nanodispersions for local delivery of peptides and recently have been employed for neurotrophic factor encapsulation [293]. Another class of nanostructures presenting very interesting properties for brain diagnostics and neuroprotection are the magnetoliposomes [294-296]. Magnetic liposomes and NPs usually constitute multifunctional nanocarriers and have shown promises in both diagnostics and therapy. Magnetic carriers can be manipulated by an external magnet and directed towards the desired targeted site ("magnetic targeting"). In addition, they can promote the nanocarrier/cell interaction and internalization ("magnetofection"). Therefore, next-generation nanotherapeutic strategies, involving multifunctional lipid NPs, could be envisaged to increase the therapeutic index of the neurotrophin drugs. Before defining the advantages and shortcomings of such new systems, future research work will be required to address the questions about the best delivery way, time of sustain release, challenges of delivery to the brain, regulation of BDNF release at individual synapses, etc.

\section{Conclusion}

Preclinical and clinical studies have shown the benefits of the neurotrophic proteins and their limitations related to the employed means of administration. Major problems in neurotrophin delivery have been related to the fact that the administered protein has not reached the degenerated and damaged neurons. Intravenous administration of neurotrophins has been inefficient, because of low permeability of the BBB to these protein molecules. Vectorization of neurotrophins can extend their circulation time and improve their bioavailability by avoiding rapid degradation and elimination from the brain. The neurotrophin half-life has been prolonged to 7-14 days using polymer carriers (microspheres, scaffolds) and even to 3-4 weeks by means of hydrogel delivery systems. The copolymer PLGA-PLL-PEG has enabled delivery of therapeutic BDNF quantities up to 60 days in in vitro studies. Blood-brain barrier penetration has been observed predominantly with receptor-mediated (Trojan horse) technologies and small-molecule non-peptide mimetics of BDNF. Peptides, mimicking the neurotrophic factor structure, have shown partial agonists actions on the TrkB receptor and have appeared to be a promising emerging strategy for treatment of neurodegenerative diseases.

It has been suggested that local long-term delivery of BDNF is necessary for beneficial neuroregenerative response. Various biocompatible carriers have been proposed for nondestructive local neurotrophin delivery and for potential therapies of neurodegenerative disorders. The strategies for local neurotrophin administration have often been based on invasive surgery. Cellular delivery has raised immunogenicity problems. However, clinical trials with encapsulated cell biodelivery (ECB) implants for targeted delivery of NGF have given strong promise in restorative neurosurgery of patients with Alzheimer's disease. Moreover, gene therapy has considerably advanced in recent years and has demonstrated the possibilities for reversal of neurological damages and for stopping of neurodegeneration. Transfers of the BDNF gene have been of therapeutic value for Huntington's 
disease and Alzheimer's disease. In perspective, non-viral gene carriers (lipoplexes, polyplexes) can be anticipated to be confirmed as advantageous over viral gene carriers, because they are non-oncogenic, non-immunogenic and easy to produce over large scales. Analysis shows that the nose-to-brain and skin-to-brain interfaces have not been sufficiently explored as non-invasive delivery strategies. This may be related to the fact that the involved mechanisms and pharmacokinetics have not been fully elucidated yet.

The fast-developing area of nanoparticle-based medicine holds the promise for emergence of new therapies for the treatment of neurodegenerative and psychiatric disorders. The neurotrophin-synthetic-NP carrier pharmacokinetics and mechanisms for BBB penetration have been scarcely studied in detail in the available reports. To avoid side effects, nanoscale delivery systems favoring targeted delivery in specific brain areas and minimizing the biodistribution to the systemic circulations should be preferably developed. Among them, it seems worth pursuing the studies on multicompartment liquid crystalline lipid NPs, incorporating omega-3 polyunsaturated fatty acids, which have been effective in promoting neurite growth and inhibition of neuronal cell apoptosis.

\section{Acknowledgments}

A.A. thanks B. Angelov for the cubosome nanoparticle modeling and for continuous collaboration. The support from the program ANR SIMI10 Nanosciences and the project "Adressage" of Laboratoire d'excellence de Recherche sur le Médicament et l'Innovation Thérapeutique (LabEx LERMIT) is gratefully acknowledged.

\section{Conflict of Interest}

The authors declare no conflict of interest.

\section{References}

1. Zuccato, C.; Cattaneo, E. Brain-derived neurotrophic factor in neurodegenerative diseases. Nat. Rev. Neurol. 2009, 5, 311-322.

2. Zuccato, C.; Cattaneo, E. Role of brain-derived neurotrophic factor in Huntington's disease. Prog. Neurobiol. 2007, 81, 294-330.

3. Fumagalli, F.; Molteni, R.; Calabrese, F.; Maj, P.F.; Racagni, G.; Riva, M.A. Neurotrophic factors in neurodegenerative disorders: Potential for therapy. CNS Drugs 2008, 22, 1005-1019.

4. Balaratnasingam, S.; Janca, A. Brain derived neurotrophic factor: A novel neurotrophin involved in psychiatric and neurological disorders. Pharmacol. Ther. 2012, 134, 116-124.

5. Nagahara, A.H.; Tuszynski, M.H. Potential therapeutic uses of BDNF in neurological and psychiatric disorders. Nat. Rev. Drug Discov. 2011, 10, 209-219.

6. Autry, A.E.; Monteggia, L.M. Brain-derived neurotrophic factor and neuropsychiatric disorders. Pharmacol. Rev. 2012, 64, 238-258.

7. Aron, L.; Klein, R. Repairing the parkinsonian brain with neurotrophic factors. Trends Neurosci. 2011, 34, 88-100. 
8. Chiocco, M.J.; Harvey, B.K.; Wang, Y.; Hoffer, B.J. Neurotrophic factors for the treatment of Parkinson's disease. Parkinsonism Relat. Disord. 2007, 13, S321-S328.

9. Deierborg, T.; Soulet, D.; Roybon, L.; Hall, V.; Brundin, P. Emerging restorative treatments for Parkinson's disease. Prog. Neurobiol. 2008, 85, 407-432.

10. Blesch, A. Neurotrophic factors in neurodegeneration. Brain Pathol. 2006, 16, 295-303.

11. Bekinschtein, P.; Cammarota, M.; Katche, C.; Slipczuk, L.; Rossato, J.I.; Goldin, A.; Lzquierdo, I.; Medina, J.H. BDNF is essential to promote persistence of long-term memory storage. Proc. Natl. Acad. Sci. USA 2008, 105, 2711-2716.

12. Bemelmans, A.P.; Horellou, P.; Pradier, L.; Brunet, I.; Colin, P.; Mallet, J. Brain-derived neurotrophic factor-mediated protection of striatal neurons in an excitotoxic rat model of Huntington's disease, as demonstrated by adenoviral gene transfer. Hum. Gene Ther. 1999, 10, 2987-2997.

13. Byerly, M.S.; Simon, J.; Lebihan-Duval, E.; Duclos, M.J.; Cogburn, L.A.; Porter, T.E. Effects of BDNF, NT-3, and corticosterone on expression of the hypothalamic obesity gene network in vivo and in vitro. Am. J. Physiol-Regul. Integr. Comp. Physiol. 2009, 296, R1180-R1189.

14. Canals, J.M.; Pineda, J.R.; Torres-Peraza, J.F.; Bosch, M.; Martin-Ibanez, R.; Munoz, M.T.; Mengod, G.; Ernfors, P.; Alberch, J. Brain-derived neurotrophic factor regulates the onset and severity of motor dysfunction associated with enkephalinergic neuronal degeneration in Huntington's disease. J. Neurosci. 2004, 24, 7727-7739.

15. Cannon, T.D.; Yolken, R.; Buka, S.; Torrey, E.F. Collaborative study group on the perinatal origins of severe psychiatric disorders. Decreased neurotrophic response to birth hypoxia in the etiology of schizophrenia. Biol. Psychiatry 2008, 64, 797-802.

16. Castrén, E.; Rantamäki, T. The role of BDNF and its receptors in depression and antidepressant drug action: Reactivation of developmental plasticity. Dev. Neurobiol. 2010, 70, 289-297.

17. Cattaneo, E.; Zuccato, C.; Tartari, M. Normal huntingtin function: An alternative approach to Huntington's disease. Nat. Rev. Neurosci. 2005, 6, 919-930.

18. Zuccato, C.; Liber, D.; Ramos, C.; Tarditi, A.; Rigamonti, D.; Tartari, M.; Valenza, M.; Cattaneo, E. Progressive loss of BDNF in a mouse model of Huntington's disease and rescue by BDNF delivery. Pharmacol. Res. 2005, 52, 133-139.

19. Fumagalli, F.; Racagni, G.; Riva, M.A. The expanding role of BDNF: A therapeutic target for Alzheimer's disease? Pharmacogenom. J. 2005, 6, 8-15.

20. Galvao, R.; Garcia-Verdugo, J.M.; Alvarez-Buylla, A. Brain-derived neurotrophic factor signaling does not stimulate subventricular zone neurogenesis in adult mice and rats. J. Neurosci. 2008, 28, 13368-13383.

21. Gielen, A.; Khademi, M.; Muhallab, S.; Olsson, T.; Piehl, F. Increased brain-derived neurotrophic factor expression in white blood cells of relapsing-remitting multiple sclerosis patients. Scand. J. Immunol. 2003, 57,493-497.

22. Gomez-Pinilla, F. Brain foods: The effects of nutrients on brain function. Nat. Rev. Neurosci. 2008, 9, 568-578.

23. Guillin, O.; Griffon, N.; Bezard, E.; Leriche, L.; Diaz, J.; Gross, C.; Sokoloff, P. Brain-derived neurotrophic factor controls dopamine D3 receptor expression: Therapeutic implications in Parkinson's disease. Eur. J. Pharmacol. 2003, 480, 89-95. 
24. Liu, Q.R.; Walther, D.; Drgon, T.; Polesskaya, O.; Lesnick, T.G.; Strain, K.J.; de Andrade, M.; Bower, J.H.; Maraganore, D.M.; Uhl, G.R. Human brain derived neurotrophic factor (BDNF) genes, splicing patterns, and assessments of associations with substance abuse and Parkinson's disease. Am. J. Med. Genet. B Neuropsychiatr. Genet. 2005, 134B, 93-103.

25. Lipsky, R.H.; Marini, A.M. Brain-derived neurotrophic factor in neuronal survival and behavior-related plasticity. Ann. N. Y. Acad. Sci. 2007, 1122, 130-143.

26. Lu, Y.; Christian, K.; Lu, B. BDNF: A key regulator for protein synthesisdependent LTP and long-term memory? Neurobiol. Learn. Mem. 2008, 89, 312-323.

27. Martinowich, K.; Manji, H.; Lu, B. New insights into BDNF function in depression and anxiety. Nat. Neurosci. 2007, 10, 1089-1093.

28. Matsumoto, T.; Rauskolb, S.; Polack, M.; Klose, J.; Kolbeck, R.; Korte, M.; Barde, Y.A. Biosynthesis and processing of endogenous BDNF: CNS neurons store and secrete BDNF, not pro-BDNF. Nat. Neurosci. 2008, 11, 131-133.

29. Matsumoto, K.; Wada, R.K.; Yamashiro, J.M.; Kaplan, D.R.; Thiele, C.J. Expression of brain-derived neurotrophic factor and p145(TrkB) affects survival, differentiation and invasiveness of human neuroblastoma cells. Cancer Res. 1995, 55, 1798-1806.

30. Monteggia, L.M.; Barrot, M.; Powell, C.M.; Berton, O.; Galanis, V.; Gemelli, T.; Meuth, S.; Nagy, A.; Greene, R.W.; Nestler, E.J. Essential role of brain-derived neurotrophic factor in adult hippocampal function. Proc. Natl. Acad. Sci. USA 2004, 101, 10827-10832.

31. Murer, M.G.; Yan, Q.; Raisman-Vozari, R. Brain-derived neurotrophic factor in the control human brain, and in Alzheimer's disease and Parkinson's disease. Prog. Neurobiol. 2001, 63, 71-124.

32. Nagahara, A.H.; Merrill, D.A.; Coppola, G.; Tsukada, S.; Schroeder, B.E.; Shaked, G.M.; Wang, L.; Blesch, A.; Kim, A.; Conner, J.M.; et al. Neuroprotective effects of brain-derived neurotrophic factor in rodent and primate models of Alzheimer's disease. Nat. Med. 2009, 15, 331-337.

33. Nakagawa, T.; Ogawa, Y.; Ebihara, K.; Yamanaka, M.; Tsuchida, A.; Taiji, M.; Noguchi, H.; Nakao, K. Antiobesity and antidiabetic effects of brain-derived neurotrophic factor in rodent models of leptin resistance. Int. J. Obes. 2003, 27, 557-565.

34. Nosheny, R.L.; Mocchetti, I.; Bachis, A. Brain-derived neurotrophic factor as a prototype neuroprotective factor against HIV-1-associated neuronal degeneration. Neurotox. Res. 2005, 8 , 187-198.

35. Perez-Navarro, E.; Alberch, J.; Neveu, I.; Arenas, E. Brain-derived neurotrophic factor, neurotrophin-3 and neurotrophin-4/5 differentially regulate the phenotype and prevent degenerative changes in striatal projection neurons after excitotoxicity in vivo. Neuroscience 1999, 91, 1257-1264.

36. Pillai, A.; Mahadik, S.P. Increased truncated TrkB receptor expression and decreased $\mathrm{BDNF} / \mathrm{TrkB}$ signaling in the frontal cortex of reeler mouse model of schizophrenia. Schizophr. Res. 2008, 100, 325-333.

37. Pillai, A. Brain-derived neurotropic factor/TrkB signaling in the pathogenesis and novel pharmacotherapy of schizophrenia. Neurosignals 2008, 16, 183-193. 
38. Rask-Andersen, M.; Olszewski, P.K.; Levine, A.S.; Schiöth, H.B. Molecular mechanisms underlying anorexia nervosa: Focus on human gene association studies and systems controlling food intake. Brain Res. Rev. 2010, 62, 147-164.

39. Robinson, R.C.; Radziejewski, C.; Spraggon, G.; Greenwald, J.; Kostura, M.R.; Burtnick, L.D.; Stuart, D.I.; Choe, S.; Jones, E.Y. The structures of the neurotrophin-4 homodimer and the brain-derived neurotrophic factor/neurotrophin-4 heterodimer reveal a common Trk-binding site. Protein Sci. 1999, 8, 2589-2597.

40. Robinson, R.C.; Radziejewski, C.; Stuart, D.I.; Jones, E.Y. Structure of brain-derived neurotrophic factor/neurotrophin-3 heterodimer. Biochemistry 1995, 34, 4139-4146.

41. Romero, M.I.; Rangappa, N.; Garry, M.G.; Smith, G.M. Functional regeneration of chronically injured sensory afferents into adult spinal cord after neurotrophin gene therapy. J. Neurosci. 2001, 21, 8408-8416.

42. Schabitz, W.R.; Berger, C.; Kollmar, R.; Seitz, M.; Tanay, E.; Kiessling, M.; Schwab, S.; Sommer, C. Effect of brain-derived neurotrophic factor treatment and forced arm use on functional motor recovery after small cortical ischemia. Stroke 2004, 35, 992-997.

43. Semkova, I.; Krieglstein, J. Neuroprotection mediated via neurotrophic factors and induction of neurotrophic factors. Brain Res. Brain Res. Rev. 1999, 30, 176-188.

44. Spina, M.B.; Squinto, S.P.; Miller, J.; Lindsay, R.M.; Hyman, C. Brain-derived neurotrophic factor protects dopamine neurons against 6-hydroxydopamine and $N$-methyl-4-phenylpyridinium ion toxicity involvement of the glutathione system. J. Neurochem. 1992, 59, 99-106.

45. Stahl, K.; Mylonakou, M.N.; Skare, O.; Amiry-Moghaddam, M.; Torp, R. Cytoprotective effects of growth factors: BDNF more potent than GDNF in an organotypic culture model of Parkinson's disease. Brain Res. 2011, 1378, 105-118.

46. Sun, Y.E.; Wu, H. The ups and downs of BDNF in Rett syndrome. Neuron 2006, 49, 321-323.

47. The BDNF Study Group (Phase III). A controlled trial of recombinant methionyl human BDNF in ALS. Neurology 1999, 52, 1427-1433.

48. Thompson, R.M.; Weickert, C.S.; Wyatt, E.; Webster, M.J. Decreased BDNF, trkB-TK and GAD67 mRNA expression in the hippocampus of individuals with chizophrenia and mood disorders. J. Psychiatry Neurosci. 2011, 36, 195-203.

49. Tsai, S.J. TrkB partial agonists: Potential treatment strategy for epilepsy, mania, and autism. Med. Hypotheses 2006, 6, 173-175.

50. Tsai, S.J. TrkB partial agonists: Potential treatment strategy for major depression. Med. Hypotheses 2007, 68, 674-676.

51. Tsao, D.; Thomsen, H.K.; Chou, J.; Stratton, J.; Hagen, M.; Loo, C.; Garcia, C.; Sloane, D.L.; Rosenthal, A.; Lin, J.C. TrkB agonists ameliorate obesity and associated metabolic conditions in mice. Endocrinology 2008, 149, 1038-1048.

52. Vu, T.Q.; Maddipati, R.; Blute, T.A.; Nehilla, B.J.; Nusblat, L.; Desai, T.A. Peptide-conjugated quantum dots activate neuronal receptors and initiate downstream signaling of neurite growth. Nano Lett. 2005, 5, 603-607.

53. Wang, Z.L.; Cheng, S.M.; Ma, M.M.; Ma, Y.P.; Yang, J.P.; Xu, G.L.; Liu, X.F. Intranasally delivered bFGF enhances neurogenesis in adult rats following cerebral ischemia. Neurosci. Lett. 2008, 446, 30-35. 
54. Alfa, R.W.; Tuszynski, M.H.; Blesch, A. A novel inducible tyrosine kinase receptor to regulate signal transduction and neurite outgrowth. J. Neurosci. Res. 2009, 87, 2624-2631.

55. Bariohay, B.; Roux, J.; Tardivel, C.; Trouslard, J.; Jean, A.; Lebrun, B. Brain-derived neurotrophic factor/tropomyosin-related kinase receptor type B signaling is a downstream effector of the brainstem melanocortin system in food intake control. Endocrinology 2009, 150, 2646-2653.

56. Boulle, F.; Kenis, G.; Cazorla, M.; Hamon, H.; Steinbusch, H.W.M.; Lanfumey, L.; van den Hove, D.L.A. TrkB inhibition as a therapeutic target for CNS-related disorders. Prog. Neurobiol. 2012, 98, 197-206.

57. Chao, M.V.; Rajagopal, R.; Lee, F.S. Neurotrophin signalling in health anddisease. Clin. Sci. 2006, 110, 167-173.

58. Chen, G.; Manji, H.K. The extracellular signal-regulated kinase pathway: An emerging promising target for mood stabilizers. Curr. Opin. Psychiatry 2006, 19, 313-323.

59. Corominas, M.; Roncero, C.; Ribases, M.; Castells, X.; Casas, M. Brain-derived neurotrophic factor and its intracellular signaling pathways in cocaine addiction. Neuropsychobiology 2007, $55,2-13$.

60. Cowansage, K.K.; LeDoux, J.E.; Monfils, M.H. Brain-derived neurotrophic factor: A dynamic gatekeeper of neural plasticity. Curr. Mol. Pharmacol. 2010, 3, 12-29.

61. Desmet, C.J.; Peeper, D.S. The neurotrophic receptor TrkB: A drug target in anti-cancer therapy? Cell. Mol. Life Sci. 2006, 63, 755-759.

62. Dwivedi, Y.; Rizavi, H.S.; Conley, R.R.; Roberts, R.C.; Tamminga, C.A.; Pandey, G.N. Altered gene expression of brain-derived neurotrophic factor and receptor tyrosine kinase $\mathrm{B}$ in postmortem brain of suicide subjects. Arch. Gen. Psychiatry 2003, 60, 804-815.

63. Ehrnhoefer, D.E.; Wong, B.K.Y.; Hayden, M.R. Convergent pathogenic pathways in Alzheimer's and Huntington's diseases: Shared targets for drug development. Nat. Rev. Drug Discov. 2011, 10, 853-867.

64. Elliott, E.; Atlas, R.; Lange, A.; Ginzburg, I. Brain-derived neurotrophic factor induces a rapid dephosphorylation of Tau protein through a PI-3 kinase signalling mechanism. Eur. J. Neurosci. 2005, 22, 1081-1089.

65. Hashimoto, K.; Koizumi, H.; Nakazato, M.; Shimizu, E.; Iyo, M. Role of brain-derived neurotrophic factor in eating disorders: Recent findings and its pathophysiological implications. Prog. Neuropsychopharmacol. Biol. Psychiatry 2005, 29, 499-504.

66. He, X.P.; Kotloski, R.; Nef, S.; Luikart, B.W.; Parada, L.F.; McNamara, J.O. Conditional deletion of TrkB but not BDNF prevents epileptogenesis in the kindling model. Neuron 2005, 43, $31-42$.

67. Kang, H.; Schuman, E.M. A requirement for local protein synthesis in neurotrophin-induced hippocampal synaptic plasticity. Science 1996, 273, 1402-1406.

68. Nishida, Y.; Adati, N.; Ozawa, R.; Maeda, A.; Sakaki, Y.; Takeda, T. Identification and classification of genes regulated by phosphatidylinositol 3-kinase- and TrkB-mediated signalling pathways during neuronal differentiation in two subtypes of the human neuroblastoma cell line SH-SY5Y. BMC Res. Notes 2008, 1, 95. 
69. Ibanez, C.F.; Ilag, L.L.; Murrayrust, J.; Persson, H. An extended surface of binding to Trk tyrosine kinase receptors in NGF and BDNF allows the engineering of a multifunctional pan-neurotrophin. EMBO J. 1993, 12, 2281-2293.

70. Jaboin, J.; Kim, C.J.; Kaplan, D.R.; Thiele, C.J. Brain-derived neurotrophic factor activation of TrkB protects neuroblastoma cells from chemotherapy-induced apoptosis via phosphatidylinositol 3'-kinase pathway. Cancer Res. 2002, 62, 6756-6763.

71. Kermani, P.; Rafii, D.; Jin, D.K.; Whitlock, P.; Schaffer, W.; Chiang, A.; Vincent, L.; Friedrich, M.; Shido, K.; Hackett, N.R.; et al. Neurotrophins promote revascularization by local recruitment of $\operatorname{TrkB}(+)$ endothelial cells and systemic mobilization of hematopoietic progenitors. J. Clin. Invest. 2005, 115, 653-663.

72. Lessmann, V.; Gottmann, K.; Malcangio, M. Neurotrophin secretion: Current facts and future prospects. Prog. Neurobiol. 2003, 69, 341-374.

73. Malcangio, M.; Lessmann, V. A common thread for pain and memory synapses? Brain-derived neurotrophic factor and TrkB receptors. Trends Pharmacol. Sci. 2003, 24, 116-121.

74. Pattarawarapan, M.; Burgess, K. Molecular basis of neurotrophin-receptor interactions. J. Med. Chem. 2003, 46, 5277-5291.

75. Rantamaäki, T.; Hendolin, P.; Kankaanpää, A.; Mijatovic, J.; Piepponen, P.; Domenici, E.; Chao, M.V.; Männistö, P.T.; Castrén, E. Pharmacologically diverse antidepressants rapidly activate brain-derived neurotrophic factor receptor TrkB and induce phospholipase-Cgamma signaling pathways in mouse brain. Neuropsychopharmacology 2007, 32, 2152-2162.

76. Yang, J.; Siao, C.J.; Nagappan, G.; Marinic, T.; Jing, D.; McGrath, K.; Chen, Z.Y.; Mark, W.; Tessarollo, L.; Lee, F.S.; et al. Neuronal release of proBDNF. Nat. Neurosci. 2009, 12, 113-115.

77. Reichardt, L.F. Neurotrophin-regulated signalling pathways. Phil. Trans. R. Soc. B 2006, 361, 1545-1564.

78. Schramm, A.; Schulte, J.H.; Astrahantseff, K.; Apostolov, O.; van Limpt, V.; Sieverts, H.; Kuhfittig-Kulle, S.; Pfeiffer, P.; Versteeg, R.; Eggert, A. Biological effects of TrkA and TrkB receptor signaling in neuroblastoma. Cancer Lett. 2005, 228, 143-153.

79. Saarelainen, T.; Hendolin, P.; Lucas, G.; Koponen, E.; Sairanen, M.; MacDonald, E.; Agerman, K.; Haapasalo, A.; Nawa, H.; Aloyz, R.; et al. Activation of the TrkB neurotrophin receptor is induced by antidepressant drugs and is required for antidepressant-induced behavioral effects. J. Neurosci. 2003, 23, 349-357.

80. Soliman, F.; Glatt, C.E.; Bath, K.G.; Levita, L.; Jones, R.M.; Pattwell, S.S.; Jing, D.; Tottenham, N.; Amso, D.; Somerville, L.H.; et al. A genetic variant BDNF polymorphism alters extinction learning in both mouse and human. Science 2010, 327, 863-866.

81. Waterhouse, E.G.; Xu, B. New insights into the role of brain-derived neurotrophic factor in synaptic plasticity. Mol. Cell Neurosci. 2009, 42, 81-89

82. Yang, T.; Yin, W.; Derevyanny, V.D.; Moore, L.A.; Longo, F.M. Identification of an ectodomain within the LAR protein tyrosine phosphatase receptor that binds homophilically and activates signalling pathways promoting neurite outgrowth. Eur. J. Neurosci. 2005, 22, 2159-2170.

83. Yoshii, A.; Constantine-Paton, M. Postsynaptic BDNF-TrkB signaling in synapse maturation, plasticity, and disease. Dev. Neurobiol. 2010, 70, 304-322. 
84. Zhang, Q.; Liu, G.; Wu, Y.; Sha, H.; Zhang, P.; Jia, J. BDNF promotes EGF-induced proliferation and migration of human fetal neural stem/progenitor cells via the PI3K/Akt pathway. Molecules 2011, 16, 10146-10156.

85. Frank, L.; Ventimiglia, R.; Anderson, K.; Lindsay, R.M.; Rudge, J.S. BDNF down-regulates neurotrophin responsiveness, TrkB protein and TrkB mRNA levels in cultured rat hippocampal neurons. Eur. J. Neurosci. 1996, 8, 1220-1230.

86. Knusel, B.; Gao, H.; Okazaki, T.; Yoshida, T.; Mori, N.; Hefti, F.; Kaplan, D.R. Ligand-induced down-regulation of Trk messenger RNA, protein and tyrosine phosphorylation in rat cortical neurons. Neuroscience 1997, 78, 851-862.

87. Sommerfeld, M.T.; Schweigreiter, R.; Barde, Y.A.; Hoppe, E. Downregulation of the neurotrophin receptor TrkB following ligand binding. Evidence for an involvement of the proteasome and differential regulation of TrkA and TrkB. J. Biol. Chem. 2000, 275, 8982-8990.

88. Agterberg, M.J.H.; Versnel, H.; van Dijk, L.M.; de Groot, J.; Klis, S.F.L. Enhanced survival of spiral ganglion cells after cessation of treatment with brain-derived neurotrophic factor in deafened guinea pigs. J. Assoc. Res. Otolaryngol. 2009, 10, 355-367.

89. Ankeny, D.P.; McTigue, D.M.; Guan, Z.; Yan, Q.; Kinstler, O.; Stokes, B.T.; Jakeman, L.B. Pegylated brain-derived neurotrophic factor shows improved distribution into the spinal cord and stimulates locomotor activity and morphological changes after injury. Exp. Neurol. 2001, 170, 85-100.

90. Aubert-Pouessel, A.; Venier-Julienne, M.C.; Clavreul, A.; Sergent, M.; Jollivet, C.; Montero-Menei, C.N.; Garcion, E.; Bibby, D.C.; Menei, P.; Benoit, J.P. In vitro study of GDNF release from biodegradable PLGA microspheres. J. Control. Release 2004, 95, 463-475.

91. Alcala-Barraza, S.R.; Lee, M.S.; Hanson, L.R.; McDonald, A.A.; Frey, W.H., II; McLoon, L.K. Intranasal delivery of neurotrophic factors BDNF, CNTF, EPO, and NT-4 to the CNS. J. Drug Target. 2010, 18, 179-190.

92. Barras, F.M.; Pasche, P.; Bouche, N.; Aebischer, P.; Zurn, A.D. Glial cell line-derived neurotrophic factor released by synthetic guidance channels promotes facial nerve regeneration in the rat. J. Neurosci. Res. 2002, 70, 746-755.

93. Benoit, J.P.; Faisant, N.; Venier-Julienne, M.C.; Menei, P. Development of microspheres for neurological disorders: From basics to clinical applications. J. Control. Release 2000, 65, 285-296.

94. Bertram, J.P.; Rauch, M.F.; Chang, K.; Lavik, E.B. Using polymer chemistry to modulate the delivery of neurotrophic factors from degradable microspheres: Delivery of BDNF. Pharm. Res. 2010, 27, 82-91.

95. Bauman, M.D.; Kang, C.E.; Stanwick, J.C.; Wang, Y.F.; Kim, H.; Lapitsky, Y.; Shoichet, M.S. An injectable dtug delivery platform for sustained combinatory therapy. J. Control. Release 2009, 138, 205-213.

96. Bloch, J.; Fine, E.G.; Bouche, N.; Zurn, A.D.; Aebischer, P. Nerve growth factor- and neurotrophin-3-releasing guidance channels promote regeneration of the transected rat dorsal root. Exp. Neurol. 2001, 172, 425-432.

97. Burdick, J.A.; Ward, M.; Liang, E.; Young, M.J.; Langer, R. Stimulation of neurite outgrowth by neurotrophins delivered from degradable hydrogels. Biomaterials 2006, 27, 452-459. 
98. Clavreul, A.; Sindji, L.; Aubert-Pouessel, A.; Benoi, J.P.; Menei, P.; Montero-Menei, C.N. Effect of GDNF-releasing biodegradable microspheres on the function and the survival of intrastriatal fetal ventral mesencephalic cell grafts. Eur. J. Pharm. Biopharm. 2006, 63, 221-228.

99. Crigler, L.; Robey, R.C.; Asawachaicharn, A.; Gaupp, D.; Phinney, D.G. Human mesenchymal stem cell subpopulations express a variety of neuro-regulatory molecules and promote neuronal cell survival and neuritogenesis. Exp. Neurol. 2006, 198, 54-64.

100. Eriksdotter-Jonhagen, M. Local delivery of NGF to basal forebrain in AD patients. Alzheimers Dement. 2010, 6, S147-S148.

101. Fine, E.G.; Decosterd, I.; Papaloizos, M.; Zurn, A.D.; Aebischer, P. GDNF and NGF released by synthetic guidance channels support sciatic nerve regeneration across a long gap. Eur. J. Neurosci. 2002, 15, 589-601.

102. Fjord-Larsen, L.; Kusk, P.; Tornoe, J.; Juliusson, B.; Torp, M.; Bjarkam, C.R.; Nielsen, M.S.; Handberg, A.; Sorensen, J.C.H.; Wahlberg, L.U. Long-term delivery of nerve growth factor by encapsulated cell biodelivery in the Göttingen minipig basal forebrain. Molec. Ther. 2010, 18, 2164-2172.

103. Frim, D.M.; Uhler, T.A.; Galpern, W.R.; Beal, M.F.; Breakefield, X.O.; Icasson, O. Implanted fibroblasts genetically engineered to produce brain-derived neurotrophic factor prevent 1-methyl-4-phenylpyridinium toxicity to dopaminergic neurons in the rat. Proc. Natl. Acad. Sci. USA 1994, 91, 5104-5108.

104. Garbayo, E.; Ansorena, E.; Lanciego, J.L.; Aymerich, M.S.; Blanco-Prieto, M.J. Sustained release of bioactive glycosylated glial cell-line derived neurotrophic factor from biodegradable polymeric microspheres. Eur. J. Pharm. Biopharm. 2008, 69, 844-851.

105. Garbayo, E.; Montero-Menei, C.N.; Ansorena, E.; Lanciego, J.L.; Aymerich, M.S.; Blanco-Prieto, M.J. Effective GDNF brain delivery using microspheres-A promising strategy for Parkinson's disease. J. Control. Release 2009, 135, 119-126.

106. Garbayo, E.; Ansorena, E.; Lanciego, J.L.; Blanco-Prieto, M.J.; Aymerich, M.S. Long-term neuroprotection and neurorestoration by glial cell-derived neurotrophic factor microspheres for the treatment of Parkinson's disease. Mov. Disord. 2011, 26, 1943-1947.

107. Gill, S.S.; Patel, N.K.; Hotton, G.R.; O’Sullivan, K.; McCarter, R.; Bunnage, M.; Brooks, D.J.; Svendsen, C.N.; Heywood, P. Direct brain infusion of glial cell line-derived neurotrophic factor in Parkinson's disease. Nat. Med. 2003, 12, 479-479.

108. Gomez, N.; Schmidt, C.E. Nerve growth factor-immobilized polypyrrole: Bioactive electrically conducting polymer for enhanced neurite extension. J. Biomed. Mater. Res. Part A 2006, 81A, $135-149$.

109. Guan, J.; Tong, W.; Ding, W.; Du, S.; Xiao, Z.; Han, Q.; Zhu, Z.; Bao, X.; Shi, X.; Wu, C.; et al. Neuronal regeneration and protection by collagen-binding BDNF in the rat middle cerebral artery occlusion model. Biomaterials 2012, 33, 1386-1395.

110. Han, Q.Q.; Sun, W.J.; Lin, H.; Zhao, W.X.; Gao, Y.; Zhao, Y.N.; Chen, B.; Xiao, Z.F.; Hu, W.; Li, Y.; et al. Linear ordered collagen scaffolds loaded with collagen-binding brain-derived neurotrophic factor improve the recovery of spinal cord injury in rats. Tissue Eng. Part A 2009, 15, 2927-2935. 
111. Hoshaw, B.A.; Malberg, J.E.; Lucki, I. Central administration of IGF-I and BDNF leads to long-lasting antidepressant-like effects. Brain Res. 2005, 1037, 204-208.

112. Houweling, D.A.; Lankhorst, A.J.; Gispen, W.H.; Bar, P.R.; Joosten, E.A.J. Collagen containing neurotrophin-3 (NT-3) attracts regrowing injured corticospinal axons in the adult rat spinal cord and promotes partial functional recovery. Exp. Neurol. 1998, 153, 49-59.

113. Jain, A.; Kim, Y.T.; McKeon, R.J.; Bellamkonda, R.V. In situ gelling hydrogels for conformal repair of spinal cord defects, and local delivery of BDNF after spinal cord injury. Biomaterials 2006, 27, 497-504.

114. Jiang, Y.; Lv, H.; Huang, S.; Tan, H.; Zhang, Y.; Li, H. Bone marrow mesenchymal stem cells can improve the motor function of a Huntington's disease rat model. Neurol. Res. 2011, 33, 331-337.

115. Jollivet, C.; Aubert-Pouessel, A.; Clavreul, A.; Venier-Julienne, M.C.; Montero-Menei, C.N.; Benoit, J.P.; Menei, P. Long-term effect of intra-striatal glial cell line-derived neurotrophic factor-releasing microspheres in a partial rat model of Parkinson's disease. Neurosci. Lett. 2004, 356, 207-210.

116. Jollivet, C.; Aubert-Pouessel, A.; Clavreul, A.; Venier-Julienne, M.C.; Remy, S.; Montero-Menei, C.N.; Benoit, J.P.; Menei, P. Striatal implantation of GDNF releasing biodegradable microspheres promotes recovery of motor function in a partial model of Parkinson's disease. Biomaterials 2004, 25, 933-942.

117. Koda, M.; Kamada, T.; Hashimoto, M.; Murakami, M.; Shirasawa, H.; Sakao, S.; Ino, H.; Yoshinaga, K.; Koshizuka, S.; Moriya, H.; et al. Adenovirus vector-mediated ex vivo gene transfer of brain-derived neurotrophic factor to bone marrow stromal cells promotes axonal regeneration after transplantation in completely transected adult rat spinal cord. Eur. Spine J. 2007, 16, 2206-2214.

118. Koda, M.; Hashimoto, M.; Murakami, M.; Yoshinaga, K.; Ikeda, O.; Yamazaki, M.; Koshizuka, S.; Kamada, T.; Moriya, H.; Shirasawa, H.; et al. Adenovirus vector-mediated in vivo gene transfer of brain-derived neurotrophic factor (BDNF) promotes rubrospinal axonal regeneration and functional recovery after complete transection of the adult rat spinal cord. J. Neurotrauma 2004, 21, 329-337.

119. Kordower, J.H.; Palfi, S.; Chen, E.; Ma, S.; Sendera, T.; Cochran, E.J.; Mufson, E.J.; Penn, R.; Goetz, C.G.; Comella, C.D. Clinico-pathological findings following intraventricular GDNF treatment in patient with Parkinson's disease. Ann. Neurol. 1999, 46, 419-424.

120. Koennings, S.; Sapin, A.; Blunk, T.; Menei, P.; Goepferich, A. Towards controlled release of BDNF-manufacturing strategies for protein-loaded lipid implants and biocompatibility evaluation in the brain. J. Control. Release 2007, 119, 163-172.

121. Krewson, C.E.; Klarman, M.L.; Saltzman, W.M. Distribution of nerve growth factor following direct delivery to brain interstitium. Brain Res. 1995, 680, 196-206.

122. Kurakhmaeva, K.B.; Djindjikhashvili, I.A.; Petrov, V.E.; Balabanyan, V.U.; Voronina, T.A.; Trofimov, S.S.; Kreuter, J.; Gelperina, S.; Begley, D.; Alyautdin, R.N. Brain targeting of nerve growth factor using poly(butyl cyanoacrylate) nanoparticles. J. Drug Target. 2009, 17, 564-574.

123. Lam, X.M.; Duenas, E.T.; Cleland, J.L. Encapsulation and stabilization of nerve growth factor into poly(lactic-co-glycolic) acid microspheres. J. Pharm. Sci. 2001, 90, 1356-1365. 
124. Lang, A.E.; Gill, S.; Patel, N.K.; Lozano, A.; Nutt, J.G.; Penn, R.; Brooks, D.J.; Hotton, G.; Moro, E.; Heywood, P.; et al. Randomized controlled trial of intraputamenal glial cell line-derived neurotrophic factor infusion in Parkinson's disease. Ann. Neurol. 2006, 59, 459-466.

125. Lebrun, B.; Bariohay, B.; Moyse, E.; Jean, A. Brain-derived neurotrophic factor (BDNF) and food intake regulation. Auton. Neurosci. Basic Clin. 2006, 126, 30-38.

126. Lee, A.C.; Yu, V.M.; Lowe, J.B.; Brenner, M.J.; Hunter, D.A.; Mackinnon, S.E.; Sakiyama-Elbert, S.E. Controlled release of nerve growth factor enhances sciatic nerve regeneration. Exp. Neurol. 2003, 184, 295-303.

127. Levivier, M.; Przedborski, S.; Bencsics, C.; Kang, U.J. Intrastriatal implantation of fibroblasts genetically engineered to produce brain-derived neurotrophic factor prevents degeneration of dopaminergic neurons in a rat model of Parkinson's disease. J. Neurosci. 1995, 15, 7810-7820.

128. Li, L.-Y.; Li, J.-T.; Wu, Q.-Y.; Li, J.; Feng, Z.-T.; Liu, S.; Wang, T.-H. Transplantation of NGF-gene-modified bone marrow stromal cells into a rat model of Alzheimer's disease. J. Mol. Neurosci. 2008, 34, 157-163.

129. Malerba, F.; Paoletti, F.; Capsoni, S.; Cattaneo, A. Intranasal delivery of therapeutic proteins for neurological diseases. Expert Opin. Drug Deliv. 2011, 8, 1277-1296.

130. Maswood, N.; Young, J.; Tilmont, E.; Zhang, Z.M.; Gash, D.M.; Gerhardt, G.A.; Grondin, R.; Roth, G.S.; Mattison, J.; Lane, M.A.; et al. Caloric restriction increases neurotrophic factor levels and attenuates neurochemical and behavioral deficits in a primate model of Parkinson's disease. Proc. Natl. Acad. Sci. USA 2004, 101, 18171-18176.

131. Maxwell, D.J.; Hicks, B.C.; Parsons, S.; Sakiyama-Elbert, S.E. Development of rationally designed affinity-based drug delivery systems. Acta Biomater. 2005, 1, 101-113.

132. Maysinger, D.; Jalsenjak, I.; Cuello, A.C. Microencapsulated nerve growth factor: Effects on the forebrain neurons following devascularizing cortical lesions. Neurosci. Lett. 1992, 140, 71-74.

133. McGuinness, S.L.; Shepherd, R.K. Exogenous BDNF rescues rat spiral ganglion neurons in vivo. Otol. Neurol. 2005, 26, 1064-1072.

134. Menei, P.; Pean, J.M.; Nerriere-Daguin, V.; Jollivet, C.; Brachet, P.; Benoit, J.P. Intracerebral implantation of NGF-releasing biodegradable microspheres protects striatum against excitotoxic damage. Exp. Neurol. 2000, 161, 259-272.

135. Moloney, T.C.; Rooney, G.E.; Barry, F.P.; Howard, L.; Dowd, E. Potential of rat bone marrow-derived mesenchymal stem cells as vehicles for delivery of neurotrophins to the Parkinsonian rat brain. Brain Res. 2010, 1359, 33-43.

136. Moore, K.; Macsween, M.; Shoichet, M. Immobilized concentration gradients of neurotrophic factors guide neurite outgrowth of primary neurons in macroporous scaffolds. Tissue Eng. 2006, 12, 267-278.

137. Nakahara, Y.; Gage, F.H.; Tuszynski, M.H. Grafts of fibroblasts genetically modified to secrete NGF, BDNF, NT-3, or basic fgf elicit differential responses in the adult spinal cord. Cell. Transplant. 1996, 5, 191-204.

138. Nomura, T.; Honmou, O.; Harada, K.; Houkin, K.; Hamada, H.; Kocsis, J.D. I.v. infusion of brain-derived neurotrophic factor gene-modified human mesenchymal stem cells protects against injury in a cerebral ischemia model in adult rat. Neuroscience 2005, 136, 161-169. 
139. Nutt, J.G.; Burchiel, K.J.; Comella, C.L.; Jankovic, J.; Lang, A.E.; Laws, E.R., Jr.; Lozano, A.M.; Penn, R.D.; Simpson, R.K., Jr.; et al. Randomized, double-blind trial of glial cell line-derived neurotrophic factor (GDNF) in PD. Neurology 2003, 60, 69-73.

140. Paradiso, B.; Marconi, P.; Zucchini, S.; Berto, E.; Binaschi, A.; Bozac, A.; Buzzi, A.; Mazzuferi, M.; Magri, E.; Mora, G.N.; et al. Localized delivery of fibroblast growth factor-2 and brain-derived neurotrophic factor reduces spontaneous seizures in an epilepsy model. Proc. Natl. Acad. Sci. USA 2009, 106, 7191-7196.

141. Pardridge, W.M.; Wu, D.F.; Sakane, T. Combined use of carboxyl-directed protein pegylation and vector-mediated blood-brain barrier drug delivery system optimizes brain uptake of brain-derived neurotrophic factor following intravenous administration. Pharm. Res. 1998, 15, $576-582$.

142. Patist, C.M.; Mulder, M.B.; Gautier, S.E.; Maquet, V.; Jerome, R.; Oudega, M. Freeze-dried poly(D,L-lactic acid) macroporous guidance scaffolds impregnated with brain-derived neurotrophic factor in the transected adult rat thoracic spinal cord. Biomaterials 2004, 25, 1569-1582.

143. Pean, J.M.; Venier-Julienne, M.C.; Boury, F.; Menei, P.; Denizot, B.; Benoit, J.P. NGF release from poly(D,L-lactide-co-glycolide) microspheres: Effect of some formulation parameters on encapsulated NGF stability. J. Control. Release 1998, 56, 175-187.

144. Pean, J.M.; Venier-Julienne, M.C.; Filmon, R.; Sergent, M.; Phan-Tan-Luu, R.; Benoit, J.P. Optimization of HSA and NGF encapsulation yields in PLGA microparticles. Int. J. Pharm. 1998, 166, 105-115.

145. Piantino, J.; Burdick, J.A.; Goldberg, D.; Langer, R.; Benowitz, L.I. An injectable, biodegradable hydrogel for trophic factor delivery enhances axonal rewiring and improves performance after spinal cord injury. Exp. Neurol. 2006, 201, 359-367.

146. Richardson, R.T.; Thompson, B.; Moulton, S.; Newbold, C.; Lum, M.G.; Cameron, A.; Wallace, G.; Kapsa, R.; Clark, G.; O'Leary, S. The effect of polypyrrole with incorporated neurotrophin-3 on the promotion of neurite outgrowth from auditory neurons. Biomaterials 2007, 28, 513-523.

147. Rosenberg, M.B.; Friedmann, T.; Robertson, R.C.; Tuszynski, M.; Wolff, J.A.; Breakefield, X.O.; Gage, F.H. Grafting genetically modified cells to the damaged brain: Restorative effects of NGF expression. Science 1998, 242, 1575-1578.

148. Sadan, O.; Bahat-Stromza, M.; Barhum, Y.; Levy, Y.S.; Pisnevsky, A.; Peretz, H.; Ilan, A.B.; Bulvik, S.; Shemesh, N.; Krepel, D.; et al. Protective effects of neurotrophic factors-secreting cells in a 6-OHDA rat model of Parkinson disease. Stem Cells Dev. 2009, 18, 1179-1190.

149. Sakane, T.; Pardridge, W.M. Carboxyl-directed pegylation of brain-derived neurotrophic factor markedly reduces systemic clearance with minimal loss of biologic activity. Pharm. Res. 1997, 14, 1085-1091.

150. Sakiyama-Elbert, S.E.; Hubbell, J.A. Controlled release of nerve growth factor from a heparin-containing fibrin-based cell ingrowth matrix. J. Control. Release 2000, 69, 149-158.

151. Sakiyama-Elbert, S.E.; Hubbell, J.A. Development of fibrin derivatives for controlled release of heparin-binding growth factors. J. Control. Release 2000, 65, 389-402. 
152. Sakiyama-Elbert, S.E.; Panitch, A.; Hubbell, J.A. Development of growth factor fusion proteins for cell-triggered drug delivery. FASEB J. 2001, 15, 1300-1302.

153. Saltzman, W.M.; Mak, M.W.; Mahoney, M.J.; Duenas, E.T.; Cleland, J.L. Intracranial delivery of recombinant nerve growth factor: Release kinetics and protein distribution for three delivery systems. Pharm. Res. 1999, 16, 232-240.

154. Schabitz, W.R.; Schwab, S.; Spranger, M.; Hacke, W. Intraventricular brain-derived neurotrophic factor reduces infarct size after focal cerebral ischemia in rats. J. Cereb. Blood Flow Metab. 1997, 17, 500-506.

155. Schabitz, W.R.; Sommer, C.; Zoder, W.; Kiessling, M.; Schwaninger, M.; Schwab, S. Intravenous brain-derived neurotrophic factor reduces infarct size and counterregulates Bax and Bcl-2 expression after temporary focal cerebral ischemia. Stroke 2000, 31, 2212-2217.

156. Scharfman, H.; Goodman, J.; Macleod, A.; Phani, S.; Antonelli, C.; Croll, S. Increased neurogenesis and the ectopic granule cells after intrahippocampal BDNF infusion in adult rats. Exp. Neurol. 2005, 192, 348-356.

157. Sharma, H.S.; Sharma, A.; Mössler, H.; Muresanu, D.F. Neuroprotective effects of cerebrolysin, a combination of different active fragments of neurotrophic factors and peptides on the whole body hyperthermia-induced neurotoxicity: Modulatory roles of co-morbidity factors and nanoparticle intoxication. Int. Rev. Neurobiol. 2012, 102, 249-276.

158. Sirianni, R.W.; Olausson, P.; Chiu, A.S.; Taylor, J.R.; Saltzman, W.M. The behavioural and biochemical effects of BDNF containing polymers implanted in the hippocampus of rats. Brain Res. 2010, 1321, 40-50.

159. Slevin, J.T.; Gash, D.M.; Smith, C.D.; Gerhardt, G.A.; Kryscio, R.; Chebrolu, H.; Walton, A.; Wagner, R.; Young, B. Unilateral intraputamenal glial cell line-derived neurotrophic factor in patients with Parkinson disease: Response to 1 year of treatment and 1 year of withdrawal. J. Neurosurg. 2007, 106, 614-620.

160. Soderquist, R.G.; Milligan, E.D.; Sloane, E.M.; Harrison, J.A.; Douvas, K.K.; Potter, J.M.; Hughes, T.S.; Chavez, R.A.; Johnson, K.; Watkins, L.R.; et al. PEGylation of brain-derived neurotrophic factor for preserved biological activity and enhanced spinal cord distribution. J. Biomed. Mater. Res. Part A 2009, 91A, 719-729.

161. Somoza, R.; Juri, C.; Baes, M.; Wyneken, U.; Rubio, F.J. Intranigral transplantation of epigenetically induced BDNF-secreting human mesenchymal stem cells: Implications for cell-based therapies in Parkinson's disease. Biol. Blood Marrow Transplant. 2010, 16, 1530-1540.

162. Son, J.H.; Chun, H.S.; Joh, T.H.; Cho, S.; Conti, B.; Lee, J.W. Neuroprotection and neuronal differentiation studies using substantia nigra dopaminergic cells derived from transgenic mouse embryos. J. Neurosci. 1999, 19, 10-20.

163. Stokols, S.; Tuszynski, M.H. Freeze-dried agarose scaffolds with uniaxial channels stimulate and guide linear axonal growth following spinal cord injury. Biomaterials 2006, 27, 443-451.

164. Takeshima, Y.; Nakamura, M.; Miyake, H.; Tamaki, R.; Inui, T.; Horiuchi, K.; Wajima, D.; Nakase, H. Neuroprotection with intraventricular brain-derived neurotrophic factor in rat venous occlusion model. Neurosurgery 2011, 68, 1334-1341. 
165. Taylor, L.; Jones, L.; Tuszynski, M.H.; Blesch, A. Neurotrophin-3 gradients established by lentiviral gene delivery promote short-distance axonal bridging beyond cellular grafts in the injured spinal cord. J. Neurosci. 2006, 26, 9713-9721.

166. Taylor, S.J.; McDonald, J.W.; Sakiyama-Elbert, S.E. Controlled release of neurotrophin-3 from fibrin gels for spinal cord injury. J. Control. Release 2004, 98, 281-294.

167. Taylor, S.J.; Rosenzweig, E.S.; McDonald, J.W.; Sakiyama-Elbert, S.E. Delivery of neurotrophin-3 from fibrin enhances neuronal fiber sprouting after spinal cord injury. J. Control. Release 2006, 113, 226-235.

168. Taylor, S.J.; Sakiyama-Elbert, S.E. Effect of controlled delivery of neurotrophin-3 from fibrin on spinal cord injury in a long term model. J. Control. Release 2006, 116, 204-210.

169. Thompson, B.C.; Moulton, S.E.; Ding, J.; Richardson, R.; Cameron, A.; O’Leary, S.; Wallace, G.G.; Clark, G.M. Optimising the incorporation and release of a neurotrophic factor using conducting polypyrrole. J. Control. Release 2006, 116, 285-294.

170. Vogelin, E.; Baker, J.M.; Gates, J.; Dixit, V.; Constantinescu, M.A.; Jones, N.F. Effects of local continuous release of brain derived neurotrophic factor (BDNF) on peripheral nerve regeneration in a rat model. Exp. Neurol. 2006, 199, 348-353.

171. Willerth, S.M.; Johnson, P.J.; Maxwell, D.J.; Parsons, S.R.; Doukas, M.E.; Sakiyama-Elbert, S.E. Rationally designed peptides for controlled release of nerve growth factor from fibrin matrices. J. Biomed. Mater. Res. Part A 2006, 80A, 13-23.

172. Williams, G.; Williams, E.J.; Maison, P.; Pangalos, M.N.; Walsh, F.S.; Doherty, P. Overcoming the inhibitors of myelin with a novel neurotrophin strategy. J. Biol. Chem. 2005, 280, 5862-5869.

173. Winter, J.O.; Cogan, S.F.; Rizzo, J.F. Neurotrophin-eluting hydrogel coatings for neural stimulating electrodes. J. Biomed. Mater. Res. Part B 2007, 81B, 551-563.

174. Wu, D. Neuroprotection in experimental stroke with targeted neurotrophins. NeuroRx 2005, 2, $120-128$.

175. Wu, D.F.; Pardridge, W.M. Neuroprotection with noninvasive neurotrophin delivery to the brain. Proc. Natl. Acad. Sci. USA 1999, 96, 254-259.

176. Xie, Y.; Ye, L.Y.; Zhang, X.B.; Cui, W.; Lou, J.N.; Nagai, T.; Hou, X.P. Transport of nerve growth factor encapsulated into liposomes across the blood-brain barrier: In vitro and in vivo studies. J. Control. Release 2005, 105, 106-119.

177. Xu, X.Y.; Yee, W.C.; Hwang, P.Y.K.; Yu, H.; Wan, A.C.A.; Gao, S.J.; Boon, K.L.; Mao, H.Q.; Leong, K.W.; Wang, S. Peripheral nerve regeneration with sustained release of poly(phosphoester) microencapsulated nerve growth factor within nerve guide conduits. Biomaterials 2003, 24, 2405-2412.

178. Yamashita, K.; Wiessner, C.; Lindholm, D.; Thoenen, H.; Hossmann, K.A. Post-occlusion treatment with BDNF reduces infarct size in a model of permanent occlusion of the middle cerebral artery in rat. Metab. Brain Dis. 1997, 12, 271-280.

179. Yang, K.; Clifton, G.L.; Hayes, R.L. Gene therapy for central nervous system injury: The use of cationic liposomes. J. Neurotrauma 1997, 14, 281-297.

180. Yang, Y.; De Laporte, L.; Rives, C.B.; Jang, J.H.; Lin, W.C.; Shull, K.R.; Shea, L.D. Neurotrophin releasing single and multiple lumen nerve conduits. J. Control. Release 2005, 104, 433-446. 
181. Yu, X.J.; Bellamkonda, R.V. Tissue-engineered scaffolds are effective alternatives to autografts for bridging peripheral nerve gaps. Tissue Eng. 2003, 9, 421-430.

182. Yu, X.J.; Dillon, G.P.; Bellamkonda, R.V. A laminin and nerve growth factor-laden three-dimensional scaffold for enhanced neurite extension. Tissue Eng. 1999, 5, 291-304.

183. Zhang, Y.; Pardridge, W.M. Conjugation of brain-derived neurotrophic factor to a blood-brain barrier drug targeting system enables neuroprotection in regional brain ischemia following intravenous injection of the neurotrophin. Brain Res. 2001, 889, 49-56.

184. Bachoud-Levi, A.C.; Deglon, N.; Nguyen, J.P.; Bloch, J.; Bourdet, C.; Winkel, L.; Rémy, P.; Goddard, M.; Lefaucheur, J.-P.; Brugières, P.; et al. Neuroprotective gene therapy for Huntington's disease using a polymer encapsulated BHK cell line engineered to secrete human CNTF. Hum. Gene Ther. 2000, 11, 1723-1729.

185. Bergen, J.M.; Park, I.K.; Horner, P.J.; Pun, S.H. Nonviral approaches for neuronal delivery of nucleic acids. Pharm. Res. 2008, 25, 983-998.

186. Blesch, A. Neurotrophin gene therapy for Alzheimer's disease. Future Neurol. 2006, 1, 179-187.

187. Blesch, A. MLV based retroviral and lentiviral vectors for in vitro and in vivo gene transfer. Methods 2004, 33, 164-172.

188. Bloch, J.; Bachoud-Levi, A.C.; Deglon, N.; Lefaucheur, J.P.; Winkel, L.; Palfi, S.; Nguyen, J.P.; Bourdet, C.; Gaura, V.; Remy, P.; et al. Neuroprotective gene therapy for Huntington's disease, using polymer-encapsulated cells engineered to secrete human ciliary neurotrophic factor: Results of a phase I study. Hum. Gene Ther. 2004, 15, 968-975.

189. Bjorklund, T.; Kirik, D. Scientific rationale for the development of gene therapy strategies for Parkinson's disease. Biochim. Biophys. Acta 2009, 1792, 703-713.

190. Bjorklund, T.; Kordower, J.H. Gene therapy for Parkinson's disease. Mov. Disord. 2010, 25, S161-S173.

191. Bowers, W.J.; Breakefield, X.O.; Sena-Esteves, M. Genetic therapy for the nervous system. Hum. Molec. Gen. 2011, 20, R28-R41.

192. Di Polo, A.; Aigner, L.J.; Dunn, R.J.; Bray, G.M.; Aguayo, A.J. Prolonged delivery of brain-derived neurotrophic factor by adenovirus-infected Muller cells temporarily rescues injured retinal ganglion cells. Proc. Nat. Acad. Sci. USA 1998, 95, 3978-3983.

193. Henry, R.A.; Hughes, S.M.; Connor, B. AAV-mediated delivery of BDNF augments neurogenesis in the normal and quinolinic acid-lesioned adult rat brain. Eur. J. Neurosci. 2007, $25,3513-3525$.

194. Kells, A.P.; Fong, D.M.; Dragunow, M.; During, M.J.; Young, D.; Connoet, B. AAV-mediated gene delivery of BDNF or GDNF is neuroprotective in a model of Huntington disease. Mol. Ther. 2004, 9, 682-688.

195. Lu, K.W.; Chen , Z.Y.; Jin, D.D.; Hou, T.S.; Cao, L.; Fu, Q. Cationic liposome-mediated GDNF gene transfer after spinal cord injury. J. Neurotrauma 2002, 19, 1081-1090.

196. Lu, P.; Jones, L.L.; Tuszynski, M.H. BDNF-expressing marrow stromal cells support extensive axonal growth at sites of spinal cord injury. Exp. Neurol. 2005, 191, 344-360. 
197. Makar, T.K.; Bever, C.T.; Singh, I.S.; Royal, W.; Sahu, S.N.; Sura, T.P.; Sultana, S.; Sura, K.T.; Patel, N.; Dhib-Jalbut, S.; et al. Brain-derived neurotrophic factor gene delivery in an animal model of multiple sclerosis using bone marrow stem cells as a vehicle. J. Neuroimmunol. 2009, $210,40-51$.

198. Munehisa, S.; Naoyuki, S.; Ryuichi, M. Experimental and clinical application of plasmid DNA in the field of central nervous diseases. Curr. Gene Ther. 2011, 11, 491-500.

199. Nakajima, H.; Uchida, K.; Yayama, T.; Kobayashi, S.; Guerrero, A.R.; Furukawa, S.; Baba, H. Targeted retrograde gene delivery of brain-derived neurotrophic factor supresses apoptosis and oligodendrolia after spinal cord injury in rats. Spine 2010, 35, 497-504.

200. Ramaswamy, S.; Kordower, J.H. Gene therapy for Huntington's disease. Neurobiol. Dis. 2012, $48,243-254$.

201. Park, H.Y.L.; Kim, J.H.K.; Kim, H.S.; Park, C.K. Stem cell-based delivery of brain-derived neurotrophic factor gene in the rat retina. Brain Res. 2012, 1469, 10-23.

202. Sayers, S.T.; Khan, N.; Ahmed, Y.; Shahid, R.; Khan, T. Preparation of brain-derived neurotrophic factor- and neurotrophin-3-secreting Schwann cells by infection with a retroviral vector. J. Mol. Neurosci. 1998, 10, 143-160.

203. Tuszynski, M.H.; Thal, L.; Pay, M.; Salmon, D.P.; Sang, U.H.; Bakay, R.; Patel, P.; Blesch, A.; Vahlsing, H.L.; Ho, G.; et al. A phase I clinical trial of nerve growth factor gene therapy for Alzheimer disease. Nat. Med. 2005, 11, 551-555.

204. Tuszynski, M.H. Nerve growth factor gene therapy in Alzheimer disease. Alzheimer Dis. Assoc. Disord. 2007, 21, 179-189.

205. Martinez-Fong, D.; Bannon, M.J.; Trudeau, L.E.; Gonzalez-Barrios, J.A.; Arango-Rodriquez, M.L.; Hernendez-Chan, N.G.; Reyes-Corona, D.; Armendariz-Borunda, J.; Navarro-Quiroqa, I. NTS-Polyplex: A potential nanocarrier for neurotrophic therapy of Parkinson's disease. Nanomedicine 2012, 8, 1052-1069.

206. Yang, L.; Rongqin, H.; Chen, J. Non-viral gene delivery and therapeutics targeting to brain. Curr. Nanosci. 2011, 7, 55-70.

207. Fletcher, J.M.; Hughes, R.A. Novel monocyclic and bicyclic loop mimetics of brain-derived neurotrophic factor. J. Pept. Sci. 2006, 12, 515-524.

208. Fletcher, J.M.; Hughes, R.A. Modified low molecular weight cyclic peptides as mimetics of BDNF with improved potency, proteolytic stability and transmembrane passage in vitro. Bioorg. Med. Chem. 2009, 17, 2695-2702.

209. Fletcher, J.M.; Morton, C.J.; Zwar, R.A.; Murray, S.S.; O’Leary, P.D.; Hughes, R.A. Design of a conformationally defined and proteolytically stable circular mimetic of brain-derived neurotrophic factor. J. Biol. Chem. 2008, 283, 33375-33383.

210. O'Leary, P.D.; Hughes, R.A. Structure-activity relationships of conformationally constrained peptide analogues of loop 2 of brain-derived neurotrophic factor. J. Neurochem. 1998, 70, 1712-1721.

211. O'Leary, P.D.; Hughes, R.A. Design of potent peptide mimetics of brain-derived neurotrophic factor. J. Biol. Chem. 2003, 278, 25738-25744. 
212. Longo, F.M.; Yang, T.; Knowles, J.K.; Xie, Y.; Moore, L.A.; Massa, S.M. Small molecule neurotrophin receptor ligands: Novel strategies for targeting Alzheimer's disease mechanisms. Curr. Alzheimer Res. 2007, 4, 503-506.

213. Massa, S.M.; Yang, T.; Xie, Y.; Shi, J.; Bilgen, M.; Joyce, J.N.; Nehama, D.; Rajadas, J.; Longo, F.M. Small molecule BDNF mimetics activate TrkB signaling and prevent neuronal degeneration in rodents. J. Clin. Invest. 2010, 120, 1774-1785.

214. Jang, S.W.; Liu, X.; Yepes, M.; Shepherd, K.R.; Miller, G.W.; Liu, Y.; Wilson, W.D.; Xiao, G.; Blanchi, B.; Sun, Y.E.; et al. A selective TrkB agonist with potent neurotrophic activities by 7,8-dihydroxyflavone. Proc. Natl. Acad. Sci. USA 2010, 107, 2687-2692.

215. Monteggia, L.M. Toward neurotrophin-based therapeutics. Am. J. Psychiatry 2011, 168, 114-116.

216. Price, R.D.; Milne, S.A.; Sharkey, J.; Matsuoka, N. Advances in small molecules promoting neurotrophic function. Pharmacol. Ther. 2007, 115, 292-306.

217. Tuinstra, H.M.; Aviles, M.O.; Shin, S.; Holland, S.J.; Zelivyanskaya, M.L.; Fast, A.G.; Ko, S.Y.; Margul, D.J.; Bartels, A.K.; Boehler, R.M.; et al. Multifunctional, multichannel bridges that deliver neurotrophin encoding lentivirus for regeneration following spinal cord injury. Biomaterials 2012, 33, 1618-1626.

218. Park, J.; Lim, E.; Back, S.; Na, H.; Park, Y.; Sun, K. Nerve regeneration following spinal cord injury using matrix metalloproteinase-sensitive, hyaluronic acid-based biomimetic hydrogel scaffold containing brain-derived neurotrophic factor. J. Biomed. Mater. Res. A 2010, 93, 1091-1099.

219. Géral, C.; Angelova, A.; Angelov, B.; Nicolas, V.; Lesieur, S. Multicompartment lipid nanocarriers for targeting of cells expressing brain receptors. In Self-Assembled Supramolecular Architectures: Lyotropic Liquid Crystals; Garti, N., Mezzenga, R., Somasundaran, P., Eds.; John Wiley \& Sons, Inc., New Jersey, NJ, USA, 2012; pp. 319-355.

220. Eriksdotter-Jönhagen, M.; Nordberg, A.; Amberla, K.; Bäckman, L.; Ebendal, T.; Meyerson, B.; Olson, L.; Seiger, A.; Shigeta, M.; Theodorsson, E.; et al. Intracerebroventricular infusion of nerve growth factor in three patients with Alzheimer's disease. Dement. Geriatr. Cogn. Disord. 1998, 9, 246-257.

221. Seiger, A.; Nordberg, A.; von Holst, H.; Bäckman, L.; Ebendal, T.; Alafuzoff, I.; Amberla, K.; Hartvig, P.; Herlitz, A.; Lilja, A.; et al. Intracranial infusion of purified nerve growth factor to an Alzheimer patient: The first attempt of a possible future treatment strategy. Behav. Brain Res. 1993, 57, 255-261.

222. Isaacson, L.G.; Saffran, B.N.; Crutcher, K.A. Intracerebral NGF infusion induces hyperinnervation of cerebral blood vessels. Neurobiol. Aging 1990, 11, 51-55.

223. Allen, S.J.; Robertson, A.G.S.; Tyler, S.J.; Wilcock, G.K.; Dawbarn, D. Recombinant human nerve growth factor for clinical trials: Protein expression, purification, stability and characterisation of binding to infusion pumps. J. Biochem. Biophys. Methods 2001, 47, 239-255.

224. Blurton-Jones, M.; Kitazawa, M.; Martinez-Coria, H.; Castello, N.A.; Mueller, F.-J.; Loring, J.F.; Yamasaki, T.R.; Poon, W.W.; Green, K.N.; LaFerla, F.M. Neural stem cells improve cognition via BDNF in a transgenic model of Alzheimer disease. Proc. Natl. Acad. Sci. USA 2009, 32, 13594-13599. 
225. Wahlberg, L.U.; Lind, G.; Almqvist, P.M.; Kusk, P.; Tornøe, J.; Juliusson, B.; Söderman, M.; Selldén, E.; Seiger, A.; Eriksdotter-Jönhagen, M.; et al. Targeted delivery of nerve growth factor via encapsulated cell biodelivery in Alzheimer disease: A technology platform for restorative neurosurgery. J. Neurosurgery 2012, 117, 340-347.

226. Brahimi, F.; Malakhov, A.; Lee, H.B.; Pattarawarapan, M.; Ivanisevic, L.; Burgess, K.; Saragovi, H.U. A peptidomimetic of NT-3 acts as a TrkC antagonist. Peptides 2009, 30, 1833-1839.

227. Peleshok, J.; Saragovi, H.U. Functional mimetics of neurotrophins and their receptors. Biochem. Soc. Trans. 2006, 34, 612-617.

228. Webster, N.J.G.; Pirrung, M.C. Small molecule activators of the Trk receptors for neuroprotection. BMC Neuroscience 2008, 9, S1:1-S1:8.

229. Adessi, C.; Soto, C. Converting a peptide into a drug: Strategies to improve stability and bioavailability. Curr. Med. Chem. 2002, 9, 963-978.

230. Begley, D.J. Delivery of therapeutic agents to the central nervous system: The problems and the possibilities. Pharmacol. Ther. 2004, 104, 29-45.

231. Boado, R.J.; Pardridge, W.M. The Trojan horse liposome technology for nonviral gene transfer across the blood-brain barrier. J. Drug Deliv. 2011, 2011, 296151:1-296151:12.

232. Xia, C.F.; Boado, R.J.; Zhang, Y.; Chu, C.; Pardridge, W.M. Intravenous glial-derived neurotrophic factor gene therapy of experimental Parkinson's disease with Trojan horse liposomes and a tyrosine hydroxylase promoter. J. Gene Med. 2008, 10, 306-315.

233. Craparo, E.F.; Bondi, M.L.; Pitarresi, G.; Cavallaro, G. Nanoparticulate systems for drug delivery and targeting to the central nervous system. CNS Neurosci. Therapeutics 2011, 17, 670-677.

234. Hughes, G.A. Nanostructure-mediated drug delivery. Nanomed. Nanotech. Biol. Med. 2005, 1, 22-30.

235. Kanwar, J.R.; Sun, X.; Punj, V.; Sriramoju, B.; Mohan, R.R.; Zhou, S.F.; Chauhan, A.; Kanwar, R.K. Nanoparticles in the treatment and diagnosis of neurological disorders: Untamed dragon with fire power to heal. Nanomed. Nanotech. Biol. Med. 2012, 8, 399-414.

236. Koo, O.M.; Rubinstein, I.; Onyuksel, H. Role of nanotechnology in targeted drug delivery and imaging. Nanomed. Nanotech. Biol. Med. 2005, 1, 193-212.

237. Modi, G.; Pillay, V.; Choonara, Y.E.; Ndesendo, V.M.; du Toit, L.C.; Naidoo, D. Nanotechnological applications for the treatment of neurodegenerative disorders. Prog. Neurobiol. 2009, 88, 272-285.

238. Nunes, A.; Al-Jamal, K.T.; Kostarelos, K. Therapeutics, imaging and toxicity of nanomaterials in the central nervous system. J. Control. Release 2012, 161, 290-306.

239. Paolino, D.; Cosco, D.; Molinaro, R.; Celia, C.; Fresta, M. Supramolecular devices to improve the treatment of brain diseases. Drug Discov. Today 2011, 16, 311-324.

240. Wong, H.L.; Wu, X.Y.; Bendayan, R. Nanotechnological advances for the delivery of CNS therapeutics. Adv. Drug Deliv. Rev. 2012, 64, 686-700.

241. Wang, Y.; Huang, L. Multifunctional theranostic nanoparticles for brain tumors. Mol. Ther. 2012, 20, 10-11.

242. Patel, M.M.; Goyal, B.R.; Bhadada, S.V.; Bhat, J.S.; Amin, A.F. Getting into the brain: approaches to enhance brain drug delivery. CNS Drugs 2009, 23, 35-58. 
243. Petros, R.A.; DeSimone, J.M. Strategies in the design of nanoparticles for therapeutic applications. Nat. Rev. Drug Discov. 2010, 9, 615-627.

244. Suh, W.H.; Suslick, K.S.; Stucky, G.D.; Suh, Y-H. Nanotechnology, nanotoxicology, and neuroscience. Prog. Neurobiol. 2009, 87, 133-170.

245. Schnyder, A.; Huwyler, J. Drug transport to brain with targeted liposomes. NeuroRx 2005, 2, 99-107.

246. Zhang, S.; Uludag, H. Nanoparticulate systems for growth factor delivery. Pharm. Res. 2009, 26, 1561-1580.

247. Mehrotra, S.; Lynam, D.; Maloney, R.; Pawelec, K.M.; Tuszynski, M.H.; Lee, I.; Chan, C.; Sakamoto, J. Time controlled protein release from layer-by-layer assembled multilayer functionalized agarose hydrogels. Adv. Funct. Mater. 2010, 20, 247-258.

248. Pang, Z.; Lu, W.; Gao, H.; Hu, K.; Chen, J.; Zhang, C.; Gao, X.; Jiang, X.; Zhu, C. Preparation and brain delivery property of biodegradable polymersomes conjugated with OX26. J. Control. Release 2008, 128, 120-127.

249. Bickel, U.; Yoshikawa, T.; Pardridge, W.M. Delivery of peptides and proteins through the blood-brain barrier. Adv. Drug Deliv. Rev. 2001, 46, 247-279.

250. Pardridge, W.M. Vector-mediated peptide drug delivery to the brain. Adv. Drug Deliv. Rev. 1995, 15, 109-146.

251. Pardgridge, W.M. Biopharmaceutical drug targeting to the brain. J. Drug Target. 2010, 18, 157-167.

252. Pardridge, W.M. Re-engineering biopharmaceuticals for delivery to brain with molecular Trojan horses. Bioconjugate Chem. 2008, 19, 1327-1338.

253. Boado, R.J.; Zhang, Y.; Zhang, Y.; Pardridge, W.M. Genetic engineering, expression, and activity of a fusion protein of a human neurotrophin and a molecular Trojan horse for delivery across the human blood-brain barrier. Biotechnol. Bioeng. 2007, 97, 1376-1386.

254. Tan, J.; Wang, Y.; Yip, X.; Glynn, F.; Shepherd, R.K.; Caruso, F. Nanoporous peptide particles for encapsulating and releasing neurotrophic factors in an animal model of neurodegeneration. Adv. Mater. 2012, 24, 3362-3366.

255. Roy, S.; Johnston, A.H.; Moin, S.T.; Dudas, J.; Newman, T.A., Hausott, B.; Schrott-Fischer, A.; Glueckert, R. Activation of TrkB receptors by NGF $\beta$ mimetic peptide conjugated polymersome nanoparticles. Nanomed. Nanotech. Biol. Med. 2012, 8, 271-274.

256. Roy, S.; Johnston, A.H.; Newman, T.A.; Glueckert, R.; Dudas, J.; Bitsche, M.; Corbacella, E.; Rieger, G.; Martini, A.; Schrott-Fischer, A. Cell-specific targeting in the mouse inner ear using nanoparticles conjugated with a neurotrophin-derived peptide ligand: Potential tool for drug delivery. Int. J. Pharm. 2010, 390, 214-224.

257. Angelov, B.; Angelova, A.; Filippov, S.; Karlsson, G.; Terrill, N.; Lesieur, S.; Štěpánek, P. Topology and internal structure of PEGylated lipid nanocarriers for neuronal transfection: Synchrotron radiation SAXS and cryo-TEM studies. Soft Matter. 2011, 7, 9714-9720.

258. Angelov, B.; Angelova, A.; Filippov, S.; Karlsson, G.; Terrill, N.; Lesieur, S.; Štěpánek, P. SAXS study of sterically stabilized lipid nanocarriers functionalized by DNA. J. Phys. Conf. Series 2012, 351, 012004:1-012004:9. 
259. Wu, H.; Li, J.; Zhang, Q.; Yan, X.; Guo, L.; Gao, X.; Qiu, M.; Jiang, X.; Lai, R.; Chen, H. A novel small Odorranalectin-bearing cubosomes: Preparation, brain delivery and pharmacodynamic study on amyloid-b25-35-treated rats following intranasal administration. Eur. J. Pharm. Biopharm. 2012, 80, 368-378.

260. Cornford, E.M.; Cornford, M.E. New systems for delivery of drugs to the brain in neurological diseases. Lancet Neurol. 2002, 1, 306-315.

261. Kabanov, A.V.; Gendelman, H.E. Nanomedicine in the diagnosis and therapy of neurodegeneratve disorders. Prog. Polym. Sci. 2007, 32, 1054-1082.

262. Buse, J.; El-Aneed, A. Properties, engineering and applications of lipid-based nanoparticle drug-delivery systems: Current research and advances. Nanomedicine 2010, 5, 1237-1260.

263. Torchilin, V.P. Recent advances with liposomes as pharmaceutical carriers. Nat. Rev. Drug Discov. 2005, 4, 145-160.

264. Cortesi, R.; Esposito, E.; Corradini, F.; Sivieri, E.; Drechsler, M.; Rossi, A.; Scatturin, A.; Menegatti, E. Non-phospholipid vesicles as carriers for peptides and proteins: Production, characterization and stability studies. Int. J. Pharm. 2007, 339, 52-60.

265. Angelova, A.; Angelov, B.; Papahadjopoulos-Sternberg, B.; Ollivon, M.; Bourgaux, C. Proteocubosomes: Nanoporous vehicles with tertiary organized fluid interfaces. Langmuir 2005, $21,4138-4143$.

266. Angelova, A.; Ollivon, M.; Campitelli, A.; Bourgaux, C. Lipid cubic phases as stable nanochannel network structures for protein biochip development: X-ray diffraction study. Langmuir 2003, 19, 6928-6935.

267. Angelova, A.; Angelov, B.; Papahadjopoulos-Sternberg, B.; Bourgaux, C.; Couvreur, P. Protein driven patterning of self-assembled cubosomic nanostructures: Long oriented nanoridges. J. Phys. Chem. B 2005, 109, 3089-3093.

268. Aota-Nakano, U.; Li, S.J.; Yamazaki, M. Effects of electrostatic interaction on the phase stability and structures of cubic phases of monoolein/oleic acid mixture membranes. Biochim. Biophys. Acta-Biomembr. 1999, 1461, 96-102.

269. Barauskas, J.; Johnsson, M.; Johnson, F.; Tiberg, F. Cubic phase nanoparticles (cubosome): Principles for controlling size, structure, and stability. Langmuir 2005, 21, 2569-2577.

270. Boomer, J.A.; Qualls, M.M.; Inerowicz, H.D.; Haynes, R.H.; Patri, V.S.; Kim, J.M.; Thompson, D.H. Cytoplasmic delivery of liposomal contents mediated by an acid-labile cholesterol-vinyl ether-PEG conjugate. Bioconjugate Chem. 2009, 20, 47-59.

271. Boyd, B.J. Characterisation of drug release from cubosomes using the pressure ultrafiltration method. Int. J. Pharm. 2003, 260, 239-247.

272. Briggs, J.; Chung, H.; Caffrey, M. The temperature-composition phase diagram and mesophase structure characterization of the monoolein/water system. J. Phys. II 1996, 6, 723-751.

273. Gustafsson, J.; Ljusberg-Wahren, H.; Almgren, M.; Larsson, K. Submicron particles of reversed lipid phases in water stabilized by a nonionic amphiphilic polymer. Langmuir 1997, 13, 6964-6971.

274. Hyde, S.T. Bicontinuous structures in lyotropic liquid crystals and crystalline hyperbolic surfaces. Curr. Opin. Solid State Mat. Sci. 1996, 1, 653-662. 
275. Larsson, K. Cubic lipid-water phases-Structures and biomembrane aspects. J. Phys. Chem. 1989, 93, 7304-7314.

276. Angelova, A.; Angelov, B.; Papahadjopoulos-Sternberg, B.; Ollivon, M.; Bourgaux, C. Structural organisation of proteocubosome carriers involving medium- and large-size proteins. J. Drug Deliv. Sci. Tech. 2005, 15, 108-112.

277. Angelova, A.; Angelov, B.; Lesieur, S.; Mutafchieva, R.; Ollivon, M.; Bourgaux, C.; Willumeit, R.; Couvreur, P. Dynamic control of nanofluidic channels in protein drug delivery vehicles. J. Drug Deliv. Sci. Tech. 2008, 18, 41-45.

278. Angelov, B.; Angelova, A.; Papahadjopoulos-Sternberg, B.; Lesieur, S.; Sadoc, J.-F.; Ollivon, M.; Couvreur, P. Detailed structure of diamond-type lipid cubic nanoparticles. J. Am. Chem. Soc. 2006, 128, 5813-5817.

279. Angelov, B.; Angelova, A.; Garamus, V.M.; Le Bas, G.; Lesieur, S.; Ollivon, M.; Funari, S.S.; Willumeit, R.; Couvreur, P. Small-angle neutron and X-ray scattering from amphiphilic stimuli-responsive diamond type bicontinuous cubic phase. J. Am. Chem. Soc. 2007, 129, 13474-13479.

280. Leesajakul, W.; Nakano, M.; Taniguchi, A.; Handa, T. Interaction of cubosomes with plasma components resulting in the destabilization of cubosomes in plasma. Colloid Surf. B Biointerfaces 2004, 34, 253-258.

281. Luzzati, V. Biological significance of lipid polymorphism: The cubic phases-Commentary. Curr. Opin. Struct. Biol. 1997, 7, 661-668.

282. Martins, S.; Sarmento, B.; Ferreira, D.C.; Souto, E.B. Lipid-based colloidal carriers for peptide and protein delivery-liposomes versus lipid nanoparticles. Int. J. Nanomed. 2007, 2, 595-607.

283. Nylander, T.; Mattisson, C.; Razumas, V.; Miezis, Y.; Hakansson, B. A study of entrapped enzyme stability and substrate diffusion in a monoglyceride-based cubic liquid crystalline phase. Colloid Surf. A Physicochem. Eng. Asp. 1996, 114, 311-320.

284. Qiu, H.; Caffrey, M. The phase diagram of the monoolein/water system: Metastability and equilibrium aspects. Biomaterials 2000, 21, 223-234.

285. Angelov, B.; Angelova, A.; Vainio, U.; Garamus, V.M.; Lesieur, S.; Willumeit, R.; Couvreur, P. Long living intermediates during a lamellar to a diamond-cubic lipid phase transition: A SAXS investigation. Langmuir 2009, 25, 3734-3742.

286. Angelov, B.; Angelova, A.; Mutafchieva, R.; Lesieur, S.; Vainio, U.; Garamus, V.M.; Jensen, G.V.; Pedersen, J.S. SAXS investigation of a cubic to a sponge (L3) phase transition in self-assembled lipid nanocarriers. Phys. Chem. Chem. Phys. 2011, 13, 3073-3081.

287. Angelova, A.; Angelov, B.; Garamus, V.M.; Couvreur, P.; Lesieur, S. Small-angle X-ray scattering investigations of biomolecular confinement, loading, and release from liquid crystalline nanochannel assemblies. J. Phys. Chem. Lett. 2012, 3, 445-457.

288. Angelov, B.; Angelova, A.; Papahadjopoulos-Sternberg, B.; Hoffmann, S.V.; Nicolas, V.; Lesieur, S. Protein-containing PEGylated cubosomic particles: Freeze-fracture electron microscopy and synchrotron radiation circular dichroism study. J. Phys. Chem. B 2012, 116, $7676-7686$. 
289. Angelova, A.; Angelov, B.; Mutafchieva, R.; Lesieur, S.; Couvreur, P. Self-assembled multicompartment liquid crystalline lipid carriers for protein, peptide, and nucleic acid drug delivery. Acc. Chem. Res. 2011, 44, 147-156.

290. Siekmann, B.; Bunjes, H.; Koch, M.M.H.; Westesen, K. Preparation and structural investigations of colloidal dispersions prepared from cubic monoglyceride-water phases. Int. J. Pharm. 2002, 244, 33-43.

291. Yaghmur, A.; Glatter, O. Characterization and potential applications of nanostructured aqueous dispersions. Adv. Colloid Interface Sci. 2009, 147-148, 333-342.

292. Al-jamal, W.T.; Kostarelos, K. Liposomes: From a clinically established drug delivery system to a nanoparticle platform for theranostic nanomedicine. Acc. Chem. Res. 2011, 44, 1094-1104.

293. Angelova, A.; Angelov, B.; Drechsler, M.; Garamus, V.M.; Lesieur, S. Protein entrapment in PEGylated lipid nanoparticles. Int. J. Pharm. 2013, submitted for publication.

294. Martina, M.S.; Fortin, J.P.; Ménager, C.; Clément, O.; Barratt, G.; Grabielle-Madelmont, C.; Gazeau, F.; Cabuil, V.; Lesieur, S. Generation of superparamagnetic liposomes revealed as highly efficient MRI contrast agents for in vivo imaging, J. Am. Chem. Soc., 2005, 127, 10676-10685.

295. Martina, M.S.; Wilhelm, C.; Lesieur, S. The effect of magnetic targeting on the uptake of magnetic-fluid-loaded liposomes by human prostatic adenocarcinoma cells. Biomaterials 2008, 29, 4137-4145.

296. Lesieur, S.; Gazeau, F.; Luciani, N.; Ménager, C.; Wilhelm, C. Multifunctional nanovectors based on magnetic nanoparticles coupled with biological vesicles or synthetic liposomes. J. Mater. Chem. 2011, 21, 14387-14393.

(C) 2013 by the authors; licensee MDPI, Basel, Switzerland. This article is an open access article distributed under the terms and conditions of the Creative Commons Attribution license (http://creativecommons.org/licenses/by/3.0/). 